\title{
Microcirculatory Disturbances in the Pathogenesis of Acute Pancreatitis
}

\author{
Dirk Uhlmann \\ 2nd Department of Surgery, University of Leipzig
}

Germany

\section{Introduction}

In acute pancreatitis, reductions in blood flow and alterations of microvascular integrity resulting in impaired tissue oxygenation play an important part in the progression and possibly the initiation of the disease. Independently of the initial noxa, the intra-pancreatic activation of trypsinogen to trypsin is the crucial trigger of acute pancreatitis. The central events for the further course are the release of local mediators (cytokines, vasoactive substances, free oxygen radicals) and subsequently the development of microcirculatory disturbances and the activation of leukocytes and their infiltration into the tissue. At present, the deterioration of microcirculation is seen as the most important pacemaker in the progression to a necrotizing pancreatitis. In addition to its potentiatory role, severe pancreatic ischemia can play a pathogenetic role in the initiation of acute pancreatitis. The acute edematous pancreatitis is characterized by an increased and homogeneous microperfusion. The experimental necrotizing pancreatitis shows a progredient decrease of capillary perfusion despite stable macrohemodynamics.

There is increasing evidence that ischemia alone may be the primary cause of pancreatitis or may be the exacerbating promotor for the progression from edematous to necrotizing pancreatitis. In clinical studies there was evidence, that ischemia during cardiopulmonary bypass triggered acute pancreatitis and acute pancreatitis was found in up to $25 \%$ of autopsies of patients dying after shock. In animal models severe pancreatitis could be induced by obstruction of terminal pancreatic arterioles. The study by Mithöfer et al. [1] demonstrates, that temporary hemorrhagic hypotension in rats per se initiates acute pancreatitis.

The hypothesis, that the manifestation of microvascular injury in acute pancreatitis involves ischemia/reperfusion(I/R)-associated events, is supported by the study of Menger et al. [2], who analyzed the pancreatic microcirculation of rats during postischemic reperfusion by use of intravital fluorescence microscopy (Fig. 1, 2). In this investigation, post-ischemic reperfusion was characterized by a significant reduction of functional capillary density (noreflow) and by a marked increase of the permanently adherent leukocytes in postcapillary venules (reflow paradox) (Fig. 3). In addition, the functional and histomorphological alterations in this study were similar to the alteration seen in edematous pancreatitis. Postischemic activation of leukocytes has been reported to determine the outcome of I/R injury. Kusterer et al. [3] have demonstrated that sodium taurocholate-induced pancreatitis 
is characterized by early arteriolar vasoconstriction with ischemia, followed by arteriolar vasodilation with reestablishment of blood flow (reperfusion). Increased leukocyteendothelial cell interactions in postcapillary venules - mimicking the I/R event - were observed during vasodilation. The concept of I/R-induced pancreatitis is mostly reflected in the clinical situation of post-transplant pancreatitis. Experimental studies using the model of syngeneic pancreas transplantation in rats show microcirculatory disturbances and cellular damages similar to those seen in the beginning of an acute pancreatitis [4]. Pancreatitis after hemorrhagic shock or hypotension with hypoxia, but not complete ischemia/anoxia may also involve pathomechanisms associated with ischemia/reperfusion. A recent study demonstrates, that hemorrhagic hypotension in rats induces intermittent capillary perfusion, which is characterized by periods of normal blood flow followed by periods of complete cessation of blood flow [5]. This type of regional ischemia and reperfusion may contribute to the manifestation of pancreatitis, independent of the etiology.

\section{Cell-cell interactions}

By means of intravital microscopy (Fig. 1-3) in conjunction with technique of selected celllabeling, direct impairments of pancreatic microcirculation induced by controlled haemorrhage or interruption of arterial blood supply to the pancreas in the early phase of acute pancreatitis have been observed [6], suggesting the pancreatic microcirculation being highly susceptible to ischemia [7-9]. The nature of blood cell-endothelium, especially leukocyte-endothelium, interactions as an early step in the inflammatory response has been characterized in experimental pancreas transplantation and in models of I/R-induced acute pancreatitis $[4,10]$.

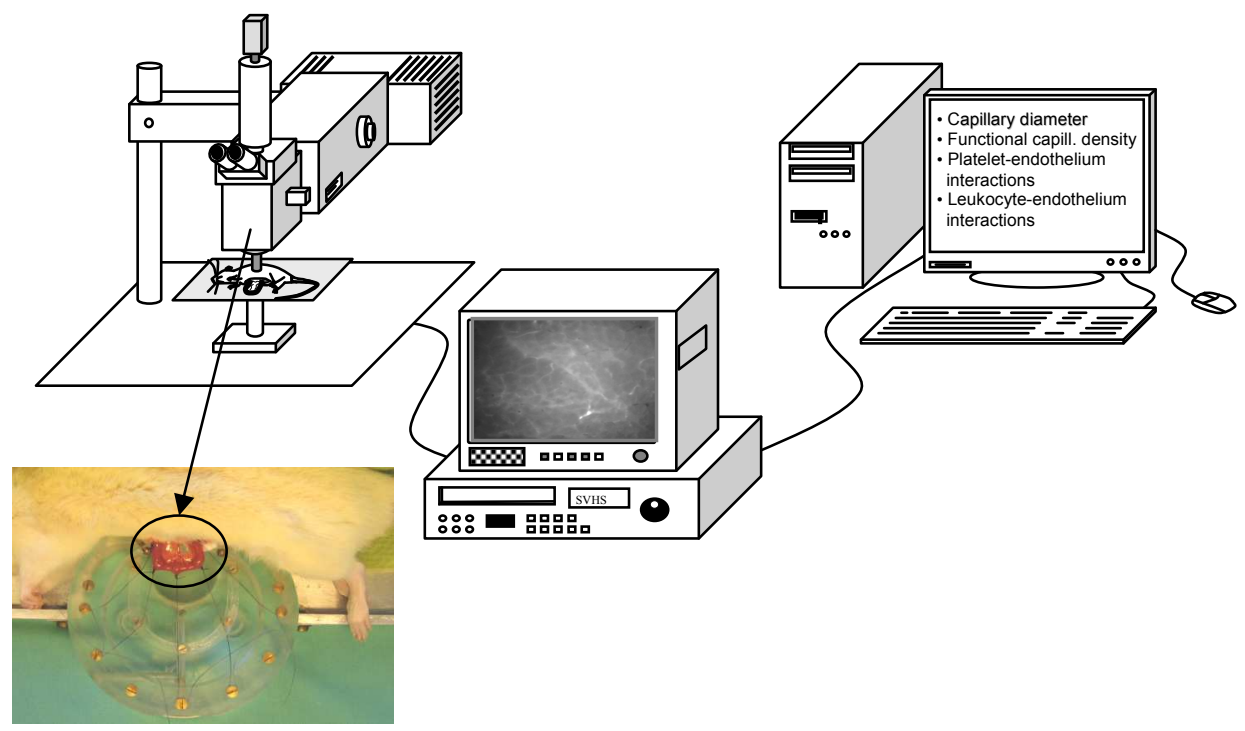

Fig. 1. Processing of intravital microscopy of the rat pancreas. 


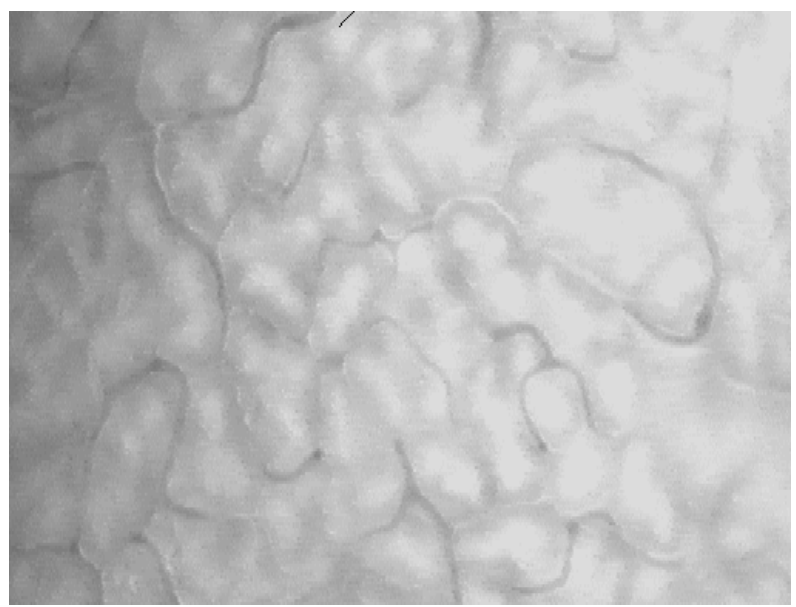

Fig. 2. In-vivo microscopic image of pancreas microcirculation.

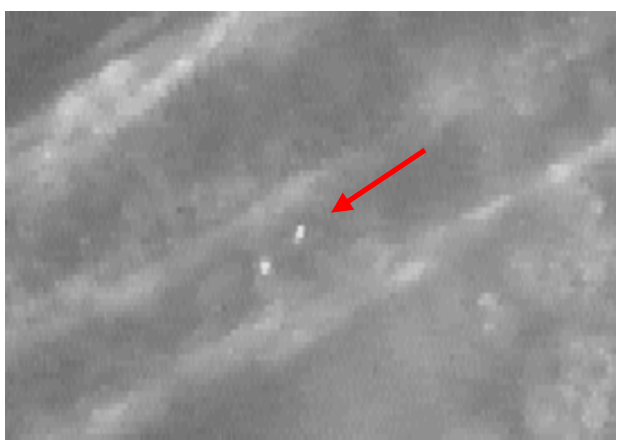

Fig. 3. In-vivo microscopic image of sticking platelets in a postcapillary venule of a postischemic rat pancreas.

\subsection{Leukocytes}

The neutrophils play a central part in the inflammatory process of acute pancreatitis. Their activation and that of the endothelium by cytokines (IL-6, TNFa, IL-8, IL-1b and others) and of proinflammatory mediators (platelet-activating factor (PAF), free radicals and others) will allow a narrow interaction between them that will result in a significant concentration of neutrophils activated in the interstitium [11-14]. This interaction takes place in three parts: a weak adhesion of the neutrophils to the endothelium, followed by a stronger adhesion and, finally, the neutrophil migration (Fig. 4). Three families of adhesion molecules are implicated: selectins, b2-integrins and immunoglobulins (Table 1). The selectins are surface glycoproteins implicated in weak adhesion. The L-selectin, expressed by the endothelial cells and the neutrophils, plays a part at the beginning of reperfusion. It interacts with the Pselectin on the neutrophils and a specific ligand present on the membrane of the neutrophil, the E-selectin-specific ligand-1 (ESL-1) [15]. Endothelial P-selectin will be expressed later 
from the Weibel-Palade bodies after activation of the endothelium by reactive oxygen species (ROS), hypercalcaemia, complement or thrombin. Its peak of expression occurs 10$20 \mathrm{~min}$ after the beginning of reperfusion [14]. It interacts with P-selectin glycoprotein ligand-1 (PSGL-1) expressed by the neutrophils. These interactions are very weak, giving the neutrophils a weak, transitory, reversible adhesion known as 'leukocyte rolling'. This phase prepares the neutrophil and the endothelium for the following stage. A more important stowing of neutrophils in the endothelium utilizes other leukocyte and endothelium proteins that have a stronger affinity for each other.

$\begin{array}{lll}\text { Leukocyte adhesion receptor } & \text { Endothelial ligand } & \text { Function } \\ \text { a4b7 (unactivated) } & \text { MadCAM-1 } & \text { Rolling } \\ \text { a4b1 (unactivated) } & \text { VCAM-1 } & \text { Rolling } \\ \text { PSGL-1 } & \text { P-selectin } & \text { Capture, Rolling } \\ \text { L-selectin } & \text { P-selectin } & \text { Capture } \\ & \begin{array}{l}\text { Peripheral node } \\ \text { addressin (PNAd) }\end{array} & \text { Rolling } \\ & \text { E-selectin } & \\ \text { MadCAM-1 } & \text { VCAM-1/MAdCAM-1 } & \text { Firm adhesion } \\ \text { a4b7 (activated) } & \text { VCAM-1 } & \text { Firm adhesion } \\ \text { CD1 (activated) } & \text { ICAM-1, ICAM-2 } & \text { Firm adhesion, } \\ \text { (LFA-1) } & \text { ICAM-1 } & \text { Emigration } \\ \text { CD11b/CD18 } & \text { PECAM-1 } & \text { Firm adhesion, } \\ \text { PECAM-1 } & \text { Emigration } \\ \end{array}$

Table 1. Leukocyte-endothelium interactions. Adhesion receptors and their ligands on activated endothelial cells. Modified from [17].

The ROS, PAF and leucotriene (LTB4) stimulate the expression by neutrophils of b2integrins from the intracellular granules. This family of membrane proteins consists of CD11a/CD18, CD11b/CD18 and CD11c/ CD18 and interacts with the ICAM-1 endothelial protein whose expression is enhanced by TNFa and IL-1 $[16,17]$. This interaction fastens the neutrophil to the surface of the endothelial cell and allows the next stage. ICAM-1 and PECAM-1 are adhesion molecules belonging to the superfamily of immunoglobulins which take part and orchestrate the transfer of the neutrophils towards the interstitium. The leukocyte extravasation utilizes many stages, not all of which are yet clear. Nevertheless, it seems that PECAM-1, localized at the level of the intercellular endothelial junctions, is 
necessary to allow neutrophil migration [18]. This transfer is facilitated by the inflammation mediators, the connection of CD11/CD18-ICAM-1 and the ROS making the endothelial barrier receptive by decreasing the expression of cadherin and phosphorylation of vascular endothelial cadherin and cathenin, components of the intercellular junctions $[19,20]$.

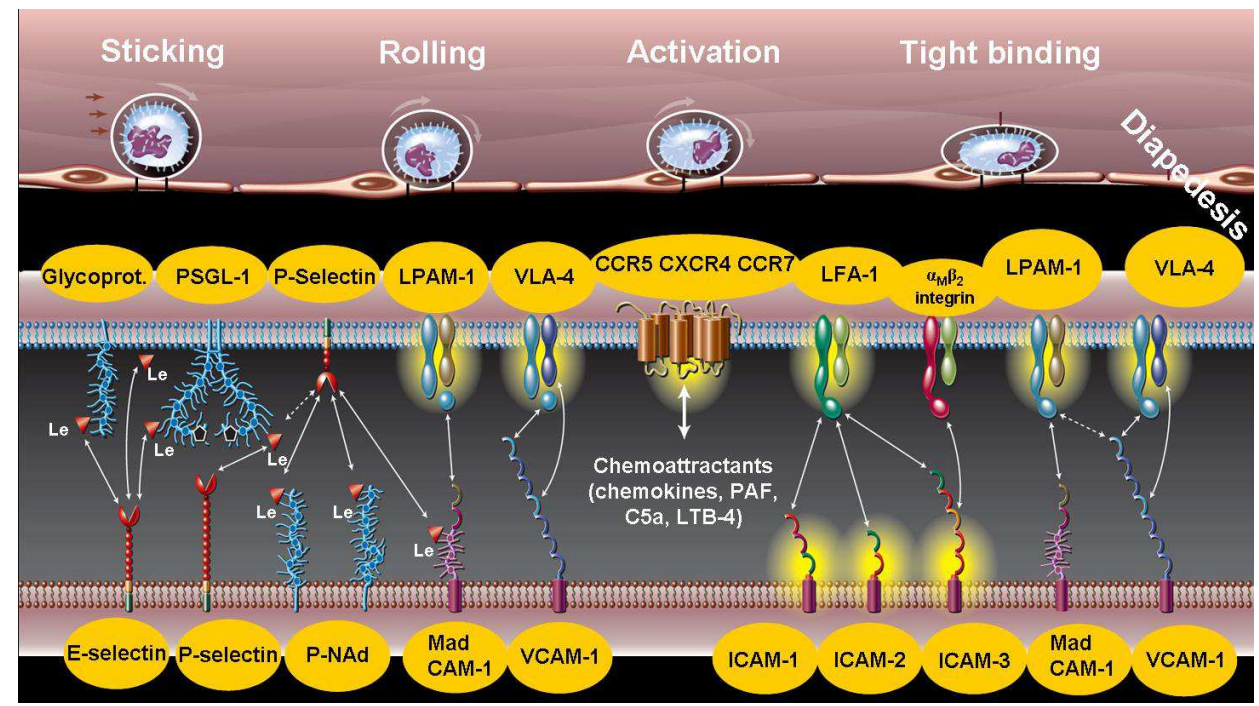

Fig. 4. Multistep adhesion cascade of leukocyte-endothelium interactions. Modified from [183].

Arriving at the interstitium, the activated neutrophil will cause considerable damage to a tissue, which has already suffered from hypoxia. These lesions are mainly related to the massive ROS production, to the release of the contents of the neutrophilic granules and to the metabolites of arachidonic acid. The last, metabolized by phospholipase A2, generates PAF and LTB4, two powerful chemoattractive components that stimulate the adhesion of neutrophils to the endothelium and their degranulation in the interstitium. The neutrophilic granules, filled with proteases, collagenases, elastases, lipooxygenases, phospholipases and myeloperoxidases, will digest and disorganize the protein network of extracellular matrix (Table 2). The proteic network of extracellular matrix is important in healing while being used to guide tissue formation. The inflammation induced by reperfusion is a major cause of the lesions observed after restoration of blood flow in an ischemic organ. The massive production of cytokines, the activation of the complement and a complex choreography of the neutrophils are the key factors and are therefore being examined in research to modulate the inflammatory reaction.

\subsection{Platelets}

Considerable evidence has accumulated that platelets can also contribute to I/R injury in several organs, such as the heart [21], lung [22], and pancreas [23]. Upon activation, platelets are able to generate reactive oxygen species and nitric oxide (NO) and can release proinflammatory mediators, such as chemokines, cytokines, growth factors, and cytotoxic proteases [24]. Therefore, platelets can potentially contribute to the manifestation of 
pancreatitis after normothermic I/R injury. In the liver of a rat model, Khandoga et al. [25] have demonstrated that platelets interact with the hepatic endothelium after $90 \mathrm{~min}$ of warm ischemia and $20 \mathrm{~min}$ of reperfusion and evoke the development of hepatic microvascular and hepatocellular injury.

\begin{tabular}{|l|l|}
\hline Leukocytes & Platelets \\
\hline Cytokines/chemokines & Cytokines/chemokines \\
IL-1, IL-2, IL-6, IL-8, IL-12 & IL-1, IL-7, IL-8 \\
IFN-a, IFN-b & RANTES \\
TNF-a, TNF-b & TNF-b \\
Transforming growth factor-b & CD40 ligand \\
Monocyte chemotactic factor-1 & Reactive oxygen species \\
Reactive oxygen species & Superoxide \\
Superoxide & Hydrogen peroxide \\
Hydrogen peroxide & Growth factors \\
Proteases & PDGF \\
Cathepsin-G & Transforming growth factor-b \\
Elastase & VEGF \\
Collagenase & Lipid mediators \\
Oxidases & Thromboxane A2 \\
Myeloperoxidase & 12-HETE \\
Lipid mediators & Procoagulants \\
Leukotrienes B4, C4 & Thrombin \\
Platelet activating factor & ADT and ATP \\
Miscellaneous & Platelet factor-4 \\
Cationic proteins & Polyphosphates \\
Histamine & \\
VEGF & \\
\hline
\end{tabular}

Table 2. Activation products released by leukocytes and platelets that may impair endothelial barrier function. Modified from [18].

Platelet activation was accompanied by leukocyte activation in a study of Hackert et al. [7]. An interaction between these two cell types has been demonstrated by different authors in the past [26-28]. Among others, P-selectin seems to be one of the most important adhesion molecules, which links the inflammatory and procoagulatory cascades and has the potency to activate leukocytes and platelets as the cellular elements of either pathway [27-30]. Besides their adherence to endothelial cells, activated platelets form stable aggregates with leukocytes. This results in a combined inflammatory and coagulatory contribution to thrombus formation and is also mediated by P-selectin and beta-integrins [31, 32]. Especially, the formation of microthrombotic vessel occlusion with microcirculatory perfusion failure and consequent ischemia, hypoxia, and tissue necrosis promote organ damage. 


\subsection{Lymphocytes}

Recent studies have implicated peripheral blood lymphocytes in Ag-independent inflammatory-mediated injury following organ reperfusion [33-36]. The contributory role of lymphocytes in I/ $\mathrm{R}$ is likely a multifactorial one.

Evidence is mounting on the importance of $\mathrm{T}$ cells in mediating both short- and long-term damage during I/R injury, which in turn could explain why I/R contributes to poor late allograft function [37, 38]. The demonstration that systemic immunosuppression (CsA, FK506) attenuates hepatocellular injury following I/R implies the involvement of $T$ lymphocytes in the pathophysiology of the injury [39, 40], data supported by Shen et al. in T-cell-deficient (nude) mice [41, 42], as well as in rats in which treatment with FTY720 prevented hepatic I/ $\mathrm{R}$ insult in parallel with massive redistribution of recirculating $\mathrm{T}$ cells from host peripheral blood into the lymph node compartment [43]. The adherence of lymphocytes in hepatic sinusoids occurs early duringreperfusion and impairs liver function following prolonged cold ischemic times [44]. Recent data have also shown that circulating CD4+ T lymphocytes may act as a cellular mediator in subacute PMN recruitment following hepatic I/R injury [38] (Table 3).

Platelet receptors

P-selectin

PSGL-1

GP1ba

GPIIb/IIIa

JAM-A

PECAM-1
Ligand

PSGL-1

P-selectin

vWF

P-selectin

Mac-1

GPIIb/IIIa

ICAM-1

(via fibrinogen)

a $v$ b3

Mac-1

PSD95/ZO-1

PECAM-1

\section{Function}

Rolling, adhesion, RANTES deposition

Rolling, adhesion and $\mathrm{P} / \mathrm{L}$ interactions

Aggregation, rolling, adhesion and $\mathrm{P} / \mathrm{L}$ interactions

Aggregation and adhesion

Aggregation and adhesion

Aggregation and adhesion

Table 3. Platelet-endothelium interactions: Potential molecular determinants. Modified from [157]

JAM-A junctional adhesion molecule-A

PECAM platelet endothelial cell adhesion molecule-1

PSGL-1 P-Selectin glycoprotein ligand-1

vWF von Willebrand factor

ZO-1 zona occludens protein-1

\section{Adhesion molecules}

A variety of adhesion molecules are implicated in the progression of disease. Intercellular adhesion molecule, platelet endothelial cell adhesion molecule 1 and endothelial leukocyte 
adhesion molecule 1 (ELAM-1) are up-regulated, expression of P- and E-selectin enhanced, and leukocytes become CD18 positive in acute pancreatitis [11].

\subsection{Intercellular Adhesion Molecule-1 (ICAM-1)}

ICAM-1, a single-chain transmembrane glycoprotein with a molecular weight of 80-110 $\mathrm{KDa}$, consists of five Ig-like domains, a hydrophobic transmembrane domain and a short cytoplasmic C-terminal domain [45]. Its ligand includes lymphocyte function- associated antigen-1 (LFA-1) and macrophage antigen-1 (Mac-1) [46]. ICAM-1 is an immunoglobulin molecule mainly expressed in vascular endothelial cells, and plays an important role especially in the process of inflammation. Under normal circumstances, it will not be expressed or just with low expression in most vessels. However, when its expression increased, it can interact with integrin on the surface of granular cells. Therefore, it can cause leukocyte migration through capillary endothelial barriers to inflammatory regions, and then cause excessive architectonic inflammatory response [47]. Experiments show that ICAM-1 high expression may cause leukocyte adhesion through endothelial cells leukocyte interaction, increase capillary permeability, reduce capillary blood flow velocity, cause pancreatic microcirculation disorder [48-50]. ICAM-1 expression correlates with histological severity and leukocyte infiltration [51], and can be upregulated by trypsin in vivo and in vitro [49]. This upregulation is mirrored by increased tissue infiltration of leukocytes and increased endothelium-leukocyte interaction.

Whereas the binding of endothelial ICAM is directly to CD18 on the leukocyte surface, the binding of platelets to the endothelium is possible via the following mechanism. I/R leads to fibrinogen deposition on microvascular endothelial cells and a corresponding accumulation of firmly adherent platelets. Experimental interventions (i.e., anti-fibrinogen antibody or ICAM-1 deficiency) that reduce the I/R-induced fibrinogen accumulation also blunt the accumulation of adherent platelets in both arterioles and venules, suggesting that the binding of fibrinogen to endothelial cell ICAM-1 creates a scaffold on the vessel wall onto which platelets can adhere using GPIIb/IIIa [52] (Table 3).

\subsection{Platelet-endothelial cell adhesion molecule (PECAM)-1}

The pancreatic circulation during acute experimental edematous pancreatitis may also be influenced by the expression of platelet-endothelial cell adhesion molecule on polymorphonuclear leukocytes. PECAM-1 expression was up-regulated in the peripheral circulation and down-regulated in the pancreatic microcirculation, suggesting that inhibition of PECAM-1 expression may improve the pathological changes associated with acute edematous pancreatitis in rats $[53,54]$.

\subsection{P-selectin}

P-selectin is normally stored in granular structures of both platelets (a-granules) and endothelial cells (Weibel-Palade bodies), from which it can be rapidly mobilized to the cell surface upon endothelial cell activation. Some vascular beds (e.g., intestine) exhibit significant basal expression of P-selectin [55], with little basal expression on inactivated circulating platelets. Several studies have addressed the contributions of platelet vs. endothelial cell P-selectin to the platelet adhesion induced by stimuli such as I/R [56, 57], [58], endotoxin [59], and TNF-a [60]. In I/R models of platelet adhesion, it appears that those models that elicit a rapid adhesion response in both venules and arterioles are entirely 
dependent on endothelial P-selectin [56], while I/R models exhibiting slow, time-dependent platelet adhesion only in venules involve both platelet and endothelial cell P-selectin [57]. A blocking mAb directed against PSGL-1, a ligand for P-selectin that is expressed on leukocytes and platelets [61], is also effective in attenuating the I/R-induced platelet adhesion observed hours after reperfusion, which further supports a role for plateletderived P-selectin [57].

\begin{tabular}{|c|c|c|c|}
\hline Influenced Paramter & Treatment & Effect & References \\
\hline Leukocytes & $\begin{array}{l}\text { Neutrophil depletion } \\
\text { Diannexin } \\
\text { Tacrolimus } \\
\text { Anti-fibrinogen antibody } \\
\text { Erythropoeitin }\end{array}$ & $\begin{array}{l}+ \\
+ \\
+\end{array}$ & $\begin{array}{l}{[57]} \\
{[42]} \\
{[158,7]} \\
{[159]} \\
{[160,161]}\end{array}$ \\
\hline Platelets & $\begin{array}{l}\text { Platelet depletion, anti- } \\
\text { platelet serum }\end{array}$ & + & [162] \\
\hline Lymphocytes & $\begin{array}{l}\text { FTY720 } \\
\text { Tacrolimus }\end{array}$ & $\begin{array}{l}+ \\
+ \\
\end{array}$ & $\begin{array}{l}{[43,163,33]} \\
{[158,7]}\end{array}$ \\
\hline ICAM-1 & $\begin{array}{l}\text { Anti-ICAM-1 antibody } \\
\text { ICAM-1-deficiency } \\
\text { Phloretin } \\
\text { Erythropoeitin }\end{array}$ & $\begin{array}{l}+ \\
+ \\
+\end{array}$ & $\begin{array}{l}{[51,164,165]} \\
{[52]} \\
{[166]} \\
{[160,161]}\end{array}$ \\
\hline P-selectin & $\begin{array}{l}\mathrm{CP}-96,345 \\
\text { Statins } \\
\end{array}$ & $\begin{array}{l}+ \\
+ \\
\end{array}$ & $\begin{array}{l}{[167]} \\
{[168-170]}\end{array}$ \\
\hline ET & $\mathrm{ET}_{\mathrm{A}}$ receptor antagonist & + & {$[79,171-173]$} \\
\hline $\mathrm{NO}$ & $\begin{array}{l}\text { L-arginine } \\
\text { Sodium nitroprusside }\end{array}$ & + & {$[174-176]$} \\
\hline TNF- $\alpha$ & $\begin{array}{l}\text { Receptor antagonist } \\
\text { Knockout mice } \\
\text { Polyclonal antibody }\end{array}$ & $\begin{array}{l}+ \\
+ \\
+ \\
\end{array}$ & $\begin{array}{l}{[177]} \\
{[178]} \\
{[90]}\end{array}$ \\
\hline IL-1 & $\begin{array}{l}\text { Receptor antagonist } \\
\text { Knockout mice }\end{array}$ & $\begin{array}{l}+ \\
+\end{array}$ & $\begin{array}{l}{[177]} \\
{[178]} \\
\end{array}$ \\
\hline IL-10 & IL-10 administration & + & {$[108,109]$.} \\
\hline PAF & PAF antagonist & + & [179], [180], [111] \\
\hline Serotonin & 5HT2 receptor antagonists & + & [119], [118] \\
\hline Bradykinin & $\begin{array}{l}\text { Bradykinin B2 receptor } \\
\text { antagonist }\end{array}$ & ++ & [181], [132] \\
\hline TXA2 & TXA2 receptor blocker & + & [182] \\
\hline VEGF & $\begin{array}{l}\text { tyrosinekinase inhibitor } \\
\text { PTK787/ZK222584 }\end{array}$ & + & {$[146]$} \\
\hline COX2 & Inhibition, depletion & + & {$[136,137]$} \\
\hline
\end{tabular}

Table 4. Therapeutic approaches to prevent or treat microcirculatory disturbances in acute pancreatitis.

The platelet adhesion elicited by bacterial endotoxin also appears to involve endothelial Pselectin [59]. However, glycoprotein (GP) Iba is the platelet ligand that appears to mediate this interaction. This glycoprotein and PSGL-1 are two platelet ligands that have been 
implicated in P-selectin-mediated platelet interactions (primarily rolling) with venular endothelial cells. Platelet GPIba also exhibits the capacity to bind to endothelial cells in a Pselectin-independent manner. vWF, which is released from Weibel-Palade bodies during endothelial cell activation, can bind to GPIba. vWF-GPIba interactions have been implicated in the platelet recruitment in mouse mesenteric venules stimulated with either calcium ionophore, A23187, or histamine [62, 63].

\section{Vasoactive mediators}

\subsection{Endothelin}

Endothelin-1 (ET-1) is a potent vasoconstrictor of the pancreatic microcirculation mainly produced by endothelial cells. The intact microvasculature is balanced by the constricting action of ET-1 and the dilating features of nitric oxide (NO), made constitutively by endothelial nitric oxide synthase (eNOS). It has been shown that ET-1 production is controlled at the transcriptional level. Up-regulation of prepro-ET-1 mRNA can be induced by numerous factors such as cytokines, angiotensin, thrombin, and TGF- $\beta$ [64]. Released from endothelial cells, ET-1 mediates transient vasodilation followed by a profound and longlasting vasoconstriction. Furthermore, ET-1 is able to induce an inflammatory response in human vascular smooth muscle cells by stimulating the synthesis and release of proinflammatory cytokines such as interleukin-6 [65]. ET-1 does not only mediate local injury, but also systemic disease.

ET affects microcirculation by:

- constriction of arterioles and venules [66, 67]

- $\quad$ release of prostaglandine E2, IL-6 and IL-8 from monocytes [68]

- $\quad$ stimulation of phospholipase A2 [69]

- $\quad$ reinforced formation of free oxygen radicals in neutrophiles [70]

- $\quad$ expression of adhesion molecules [71, 72]

- $\quad$ stimulation of catecholamine release [73]

Beside its vasoconstrictive effects endothelin as multifunctional cytokine modulates the motility and secretion of the intestinum, stimulates mitogenesis and acts as a growth factor.

Several investigators have shown that the pancreas is especially susceptible to ET-1 [74], [75]. The study of Hildebrand et al. showed that the rat pancreatic acini possess $\mathrm{ET}_{\mathrm{A}}$ and $\mathrm{ET}_{\mathrm{B}}$ receptors [76]. At doses of 100 to $1000 \mathrm{pmol} / \mathrm{kg}$ via intravenous injection, endothelins cause sustained reduction in pancreatic blood flow in the rabbit and dog of up to $80 \%[75,77]$. In a study in rats, intravenous infusion of endothelin-1 or alcohol significantly reduced pancreatic capillary blood flow. The deterioration of capillary blood flow was more pronounced when alcohol and ET-1 were combined [78]. Liu et al. observed a decrease of pancreatic blood flow and a reinforcement of morphological changes after application of endothelin to rats with cerulein-induced edematous pancreatitis [47]. Foitzik et al. found in transgenic rats with an overexpression of endothelin receptors a more severe course of a necrotizing pancreatitis, which could be moderated by the application of a selective $\mathrm{ET}_{\mathrm{A}}$ receptor antagonist [79]. Plusczyk et al. showed that topical ET-1 application leads to a decrease in blood flow in the pancreas [80]. In intravital microscopy a strong heterogeneity of erythrocyte velocity, a decrease in the number of perfused capillaries and a reduction of the capillary width were seen. This group suggests that high local ET concentrations can cause complex microcirculatory disturbances, leading to acinar cell necrosis and therefore to the development of necrotizing pancreatitis [80]. There is some evidence that endothelins 
also increase pancreatic capillary permeability [74, 81], though this might be explained by the resulting portal venous vasoconstriction.

\subsection{Nitric oxide}

Nitric oxide (NO) is synthetized through NO synthases from the amino acid L-arginine. For the first time, this pathway was described in endothelial cells [82], but it is also found in platelets, macrophages and in cells of the pancreas [68,69]. NO causes a relaxation of vascular smooth muscle cells, depression of platelet aggregation and adhesion and reduces the leukocyte activation in vitro [72, 83]. Reduced NO formation reinforces leukocyte adhesion and migration [84-87]. These effects are regulated by the activation of the soluble guanylatcyclase which leads to increased concentrations of cGMP in the effector cells [86]. $\mathrm{NO}$ may also act as scavanger of oxygen free radicals [88]. However, also cytotoxic effects are described [89]. The overproduction of NO by inducible NO synthetase is an important factor in the hemodynamic disturbances of several inflammatory states.

\section{Cytokines}

During acute pancreatitis, some inflammatory cells and pancreatic tissues release inflammatory mediators and cytokines, which influence the whole process of inflammation. The most important cytokines are tumor necrosis factor-a (TNF-a), interleukins (IL) and transforming growth factor (TGF).

\subsection{TNF- $\alpha$}

Lipsett [90] and Hirota et al. [91] independently proved that the levels of inflammatory cytokines always increase during acute pancreatitis and that the degree of the increase is closely linked to the severity of the disease. Many other studies have reported that selftissue injured with over-activated neutrophil leucocytes is an important causal factor of systemic complications [92-94]. One proposal is that the neutrophilic granulocyte may generate and release inflammatory cytokines such as TNF- $\alpha$ following inflammatory stimulation [95, 96]. TNF- $\alpha$ is an important species of inflammatory cytokines that participates in the pathomechanism during pancreatitis. Hughes et al. [97] found that injecting TNF-a antibody into rats can markedly improve the state and survival of rats with necrotizing pancreatitis, thereby indicating the important role of TNF- $\alpha$ in the onset and progression of the disearse. A number of mechanisms have been proposed for TNF-ainduced pancreatic injury. TNF- $\alpha$ can directly injure pancreatic duct cells and cause microthrombus, pancreatic acinus ischemia, hemorrhage, necrosis, inflammation and edema [6]. When the quantity of produced TNF-a exceeds that of the tissue TNF receptor, the excessive free TNF- $\alpha$ will enter the blood circulation, activate neutrophilic granulocytes and cause their aggregatione. It then stimulates the release of cytokines, such as IL-1b, IL-8 and IL-6 [98], causing a cytokine cascade reaction that promotes the local and systemic injury. The continuous existence of TNF-a may enhance the expression of endothelium adhesion molecules, which is necessary for the aggregation of inflammatory cells. Numerous granulocytes invade the pancreatic and renal tissues, increase granulocyte phagocytosis and degranulation, generate oxygen-derived free radicals, lysosomes, elastin enzyme, among others, and cause cell metabolic disturbances and renal failure [99]. 


\subsection{IL-1}

Interleukin (IL) IL-1 is a pro-inflammatory cytokine generated by the pancreas that plays an important role in the early stage of severe acute pancreatitis. In a animal model, the IL-1 receptor antagonist (IL-1r) has been found to decrease case fatality by $30 \%$ [100]; in addition, the IL-1 receptor can markedly lower the concentrations of IL-6 and TNF-a [101]. Fink et al. [102] administered the IL-1 receptor antagonist before inducing the pancreatitis model and found that the IL-1 receptor block markedly lowered the release of amylopsin and pancreatic necrosis in a dose-dependent manner.

The generation of IL- $1 b$ formed from IL-1 through the mediation of IL-1 convertase (ICE). IL-1 $\beta$ and TNF-a have many of the same biological activities, including pyrogen functions, the promotion of cell catabolism, the production of protein in the acute reaction period, effecting the secretion of PGI2 by epithelial cells and platelet activating factor, among others, that will cause the expansion of the inflammation area and increase the levels of inflammatory mediators, destructive enzymes and ROS secretion. IL-1b can interact with TNF-a to induce or aggravate organ injury. It also has chemotaxis and activating effects on granulocyte and can stimulate the production of other inflammatory mediators, such as IL8, IL-6 and other inflammatory cytokines, through autocrine or paracrine mechanisms.

\subsection{IL-6}

IL-6 is mainly generated by mononuclear macrophages, which have extensive inflammation-promoting effects, such as promoting the activation and proliferation of $\mathrm{B}$ cells and their final differentiation into plasmocytes, increasing immunoglobulin synthesis, promoting $\mathrm{T}$ cell differentiation and proliferation, promoting the acute period reaction and injuring tissue. The level of IL-6 in the serum can reflect the state of necrotizing acute pancreatitis. There are marked differences between acute pancreatitis patients without complications and severe acute pancreatitis patients with complications in terms of IL-6 levels. When present at levels of over $40 \mu \mathrm{l}$, IL- 6 is considered to be an indication index of severe acute pancreatitis [103]. Relevant data show that IL-1 and IL-6 can act on endothelial cells, causing them to lower their thrombomodulin activity, aggravate renal ischemia, form thrombus [104] and activate inflammatory cells to release NO and ROS to directly cause renal injury.

\subsection{IL-8}

IL-8 is a potent neutrophilic granulocyte chemotatic factor and activating factor that is mainly generated by neutrophilic granulocytes. Generated by mononuclear/ macrophages and endothelial cells, it can activate and induce T and B cell differentiation, enhance NK cells for killing target cells, promote phagocytosis and play an important role in tissue injury mediated by neutrophilic granulocytes. It is currently believed that most inflammatory reactions induced by TNF-a, IL-1 and IL-6 are realized by inducing the generation of chemotactic factors, mainly IL-8. Studies have shown that during necrotizing acute pancreatitis the levels of IL-6 and IL- 8 always increase concurrently and that these positively correlate with the state of severe acute pancreatitis [105].

\subsection{Transforming growth factor (TGF)}

Kimura et al. [106] studied the expression of TGF-b1 by means of immune electron microscopy and found that a marked effusion of the polymorphonuclear leukocyte and deposition of fibronectin and TGF-b1 among pancreatic lobules and inside lobules within 
12-24 $\mathrm{h}$ after inducing pancreatitis. They therefore believed that this kind of change at the early stage of pancreatitis is related to the generation of fibronectin and type III collagen in the extracellular matrix during the reparative process of pancreatic tissues. Konturek et al. [107] proposed that TGF-b can induce non-inflammatory apoptosis to repair injured pancreatic tissues.

\subsection{IL-10}

Interleukin-10 (IL-10) is an anti-inflammatory cytokine. Its plasma levels are elevated in animal models of endotoxemia and inhibit the release of pro-inflammatory cytokines (i.e. IL$1 \beta$, IL-6 and TNF- $\alpha$ ) from monocytes/macrophages thus preventing subsequent tissue damage. IL-10 also stimulates production of naturally occurring IL-1 receptor antagonist (IL1ra) and release of soluble p75 TNF receptor [108]. IL-10 is believed to have a protective role in acute pancreatitis. Administration of IL- 10 in experimental acute pancreatitis reduces the local inflammatory response and subsequent mortality [108, 109].

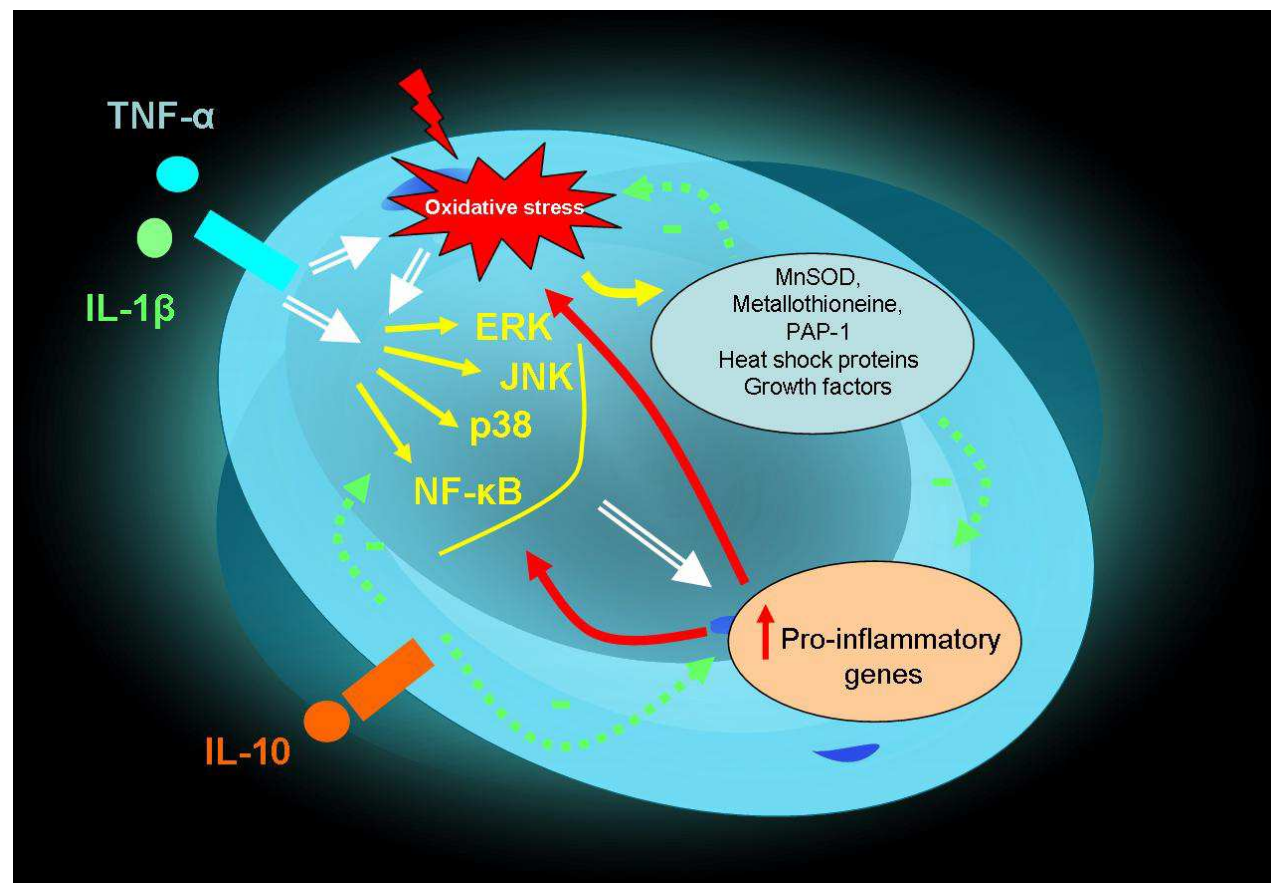

Fig. 5. Interaction between cytokines and oxidative stress in the inflammatory response in acute pancreatitis (IL-1 $\beta$ : interleukin-1 $\beta$; IL-10: interleukin 10; MnSOD: Mn-superoxide dismutase; PAP-I: pancreatitis-associated protein I; TNF-: tumor necrosis factor $\alpha$; NF-kB: nuclear factor kappaB; ERK: extracellular signal regulated kinases; JNK: c-jun N-terminal kinases; p38: p38 kinase). Modified from [184]. 


\section{Other mediators}

\subsection{Platelet activating factor (PAF)}

PAF, 1-O-octadecyl-2-acetyl-sn-glycero-3-phosphocholine, is a potent inflammatory mediator produced by endothelial cells, platelets, monocytes, neutrophils, and basophils. It is considered to be the key inflammatory mediator in severe acute pancreatitis external secretion and local/systemic inflammatory reactions [110].

PAF has been shown to be released into the peritoneal fluid as well as the bloodstream and the lung after the induction of acute experimental pancreatitis. Locally, PAF acts on microvascular diameter, permeability and platelet and leukocyte rolling, adhesion and migration through different mechanisms, including synthesis and release of $\mathrm{NO}$ and arachidonic acid metabolites, and up-regulated expressions of ICAM-1 and CD11/CD18. Secondary actions include the elevation of adhesion factor b2-integrin, changes in the endothelial cell skeleton, increases in capillary permeability, massive effusion of plasma, increase in blood viscosity and a slowdown of blood flow. It also participates in I/R injury and stimulates other vasoactive substances, including the generation of cytokine and inflammatory mediators. In acute pancreatitis, PAF levels rise due to the cytokine cascade reaction activated by elevated levels of TNF-a [98]. On the one hand, PAF promotes granulocyte aggregation and aggravates inflammatory reactions; on the other hand, it increases capillary permeability and aggravates renal tubule injury. The imbalance between PAF and vasoactive substances can initiate a vicious cycle that leads to a series of chain reactions and amplifying reactions - the cascade reaction. This reaction can increase tissue and organ injury, cause systemic inflammatory reaction syndrome (SIRS) and, eventually, multiple organ dysfunction syndrome (MODS) and/or multiple organ failure (MOF), or even death [98], [48]. Clinical studies have found that PAF antagonist Lexipafant has clear treatment effects on multiple organ failure of severe acute pancreatitis patients and also lowers the serum levels of inflammatory mediators such as IL-8 and IL-6 [111].

\subsection{Activation of complement}

$\mathrm{I} / \mathrm{R}$ activates the complement and the formation of many inflammatory mediators, including the anaphylatoxins $\mathrm{C} 3 \mathrm{a}, \mathrm{C} 4 \mathrm{a}$ and $\mathrm{C} 5 \mathrm{a}$. These recruit and stimulate the inflammatory cells and increase the expression of adhesion molecules such as vascular cell adhesion molecule-1 (VCAM-1), ICAM-1, E-selectin and P-selectin on the surface of the endothelium and the neutrophils $[112,113]$. C5a is a chemotactic factor that directly stimulates the synthesis and the leucocyte secretion of cytokines such as IL-1 and 6, the monocytes chemo-attractive protein-1 (MCP-1) and TNFa. The iC3b takes part in the adhesion of the neutrophils on the endothelium. C5b-9, known as the 'final cytolytic membrane attack complex complement', is a powerful chemotactic agent, which causes direct lesions to the endothelial cells, stimulates the endothelial production of IL-8, MCP-1 and ROS and inhibits endothelium-dependent vasodilatation [13, 113, 114].

\subsection{Serotonin}

Platelet serotonin (hydroxytryptamine; p-5HT) is an index of platelet activation [115, 116]. Furthermore, the administration of human pancreatic fluid caused the release of 5HT in parallel with platelet activation [117]. Several studies showed that the production of 5HT can induce further platelet aggregation and 5HT release [118, 119], a positive feedback that may lead to thrombus formation [120]. Furthermore, 5HT is also a potent vasoconstrictor 
[116]. Thus, these proprieties may mean that this bioamine is an aggravating factor for acute pancreatitis. The release of serotonin is considered to be the "gold standard" assay for the detection of platelet activation [121].

\subsection{Bradykinin}

The neuropeptide bradykinin is well known for its actions as an endothelium-dependent vasodilator. Bradykinin induces relaxation of vascular smooth muscle via stimulation of B2 receptors, which in turn stimulates constitutively expressed endothelial nitric oxide (NO) synthase (eNOS) to produce NO, induces cyclooxygenase-dependent production of prostacyclin and other prostanoids, as well as superoxide, activates charybdotoxin-sensitive $\mathrm{K}+$ channels, and induces the formation of epoxyeicosatrienoic acids by cytochrome $\mathrm{P}-450$ epoxygenase [122-124]. In addition to its actions on arterial and arteriolar vascular smooth muscle, bradykinin also exerts powerful pro-inflammatory effects in postcapillary venules. For example, it generates the release of endothelium-derived mediators from cultured endothelial cells that are chemotactic for neutrophils, eosinophils, monocytes, and pulmonary alveolar macrophages; induces the expression of endothelial adhesion molecules; and provokes leukocyte and platelet adherence to endothelial monolayers and postcapillary venules [125-129].

The specific mechanisms of bradykinin in the pancreas can be listed as follows: bradykinin can promote the synthesis and release of $\mathrm{NO}$, bradykinin influences the pancreatic microcirculation by stimulating the formation of reactive oxygen species, PAF, ET, and different inflammatory mediators.

\subsection{Thromboxane A2 (TXA2)}

TXA2 is a potent capillary vasoconstrictor substance and platelet aggregation promoter that is able to induce platelet release and secretion, cause local and/or systemic disturbance of hemorrhage blood coagulation and destroy the cell-protection mechanism [130, 131]. Effected by increased phospholipase during acute pancreatitis condition, the cell membrane phospholipids decompose arachidonic acid, evoke TXA2 increase, lead to platelet aggregation, thrombosis, induce platelet deformation, adhesion, result in coagulation dysfunction, precipitate pancreatic ischemia and microcirculation, and increase pancreatic pathology injury [132]. In addition, it can promote neutrophil cell activation, release ROS, injure capillary endothelial cells, result in increased capillary permeability, and plasma extravasation [133].

\subsection{Cyclooxygenase (COX)}

COX, the key enzyme for prostaglandin synthesis, exists in two isoforms as COX-1 and COX-2. COX-1 is constitutively expressed in most tissues and has been suggested to mediate the synthesis of prostaglandins required for physiological functions and maintenance of organ integrity. COX-2 is undetectable in most tissues in normal condition, but is highly inducible by cytokines, mitogens, and endotoxins, and is responsible for an increased production of prostaglandins during inflammation [134, 135]. The role of COX-2 in pancreatic pathology is unclear. Studies performed by Song et al. [136], and Ethridge et al. [137], with mice have shown that pharmacological inhibition of COX-2 or COX-2 gene disruption reduces the severity of pancreatitis and pancreatitis-associated lung injury. 
Furthermore, Foitzik et al. [138], found some beneficial systemic effects of COX-2 inhibition on acute pancreatitis, such as an improvement of renal and respiratory function, but they have not observed any significant effect of COX-2 inhibition on histological score of pancreatic damage or plasma level of trypsinogen activation peptides. Warzecha et al. [135] investigated the role of the blockade of COX-1 or COX-2 and found a significantly reduction of serum lipase and serum poly-C ribonuclease activity, as well as decreased pancreatic edema and inflammatory infiltration in morphological features in animals with ceruleininduced pancreatitis.

\subsection{Prostaglandin $12\left(\mathrm{PGI}_{2}\right)$}

PGI2 is also one of the arachidonic acid metabolites with a strong vasodilator effect. The main influence on pancreatic microcirculation in pancreatitis can be listed as follows: expansion of the pancreatic bed to increase pancreatic blood supply, improvement of pancreatic microcirculation, and increase of pancreatic blood flow by inhibiting platelet aggregation, adhesion and deformation. Furthermore, $\mathrm{PGI}_{2}$ can also stabilize lysosomalmembrane to prevent cytokine release and attenuate inflammatory response [139], [140].

\subsection{Nuclear factor-kappa B (NF-kappa B)}

NF-kappa B is a multi-purpose nuclear transcription factor, mainly involved in the regulation of expression referring to immune and inflammatory molecules [141]. Under the normal physiological circumstances, the NF-kappa B exists in the cytoplasm of other cells in the form of inactivity. When it is activated, it will promote a variety of cytokines gene transcription, and it plays an important role in cytokine-mediated infection, inflammation, oxidative stress, cell proliferation and apoptosis, the process of microcirculation and so on. Shi et al. showed that NF-kappa B activation can aggravate acute pancreatitis microcirculation disorder and gradually reduce the amplitude of pancreatic blood flow, and slow down blood flow velocity with the gradual increase of NF-kappa B P65 expression. The possible acting mechanism of NF-kappa B is that the excessive expression of NF-kappa B induces inflammatory cells' excessive secretion of nitric oxide, and then causes dysfunction of endothelial cells and smooth muscle cells, and capillary tension disorders, and leads to capillary pathological expansion, increase in capillary permeability due to endothelial cell injury, and plasma extravasation, which eventually leads to reduction of effective blood volume, pancreatic tissue hypoperfusion, and induces increases microcirculation disorder [142].

\subsection{Vascular endothelial growth factor (VEGF)}

VEGFs are endogenous vascular peptides that result in angiogenesis, vasodilatation and increased microvascular permeability in vivo [143]. Induction of VEGF mainly occurs in response to hypoxia [144]. Warzecha et al. found an increase in the immunohistochemical expression of VEGF even in the early course of I/R-induced acute pancreatitis [145]. Using the novel tyrosinekinase inhibitor PTK787/ZK222584, von Dobschuetz et al. observed a significant decrease of macromolecular permeability and a slightly increased functional capillary density with reduced leukocyte-endothelium interactions in the treatment group supporting a beneficial effect of this approach [146]. 


\subsection{Role of endotoxin}

Endotoxin, which is mainly produced by Gram-negative bacteria, is a component of the lipopolysaccharide present in cell walls. Clinical studies show that endotoxemia occurs in acute pancreatitis and particularly in severe acute pancreatitis, and that it is closely related to the onset, progression and complication of multiple organ failure in severe acute pancreatitis. Windsor et al.'s [147] study demonstrated the link between endotoxin and the state of pancreatitis. Other researchers studying the relation between plasma endotoxin levels of acute pancreatitis patients and multiple organ injury have found that endotoxin has an important promoting effect during the progression of multiple organ injury. As the most potent stimulant of endothelin, endotoxin can elevate the endothelin level in vivo and in blood, potently contracting medium-sized arteries and arterioles. Increased endothelin levels will also aggravate ischemia in other tissues, enhance bacterial translocation, raise blood endotoxin and renin-angiotensin levels and form a vicious cycle chain of tissue ischemia and endothelin that aggravates tissue ischemia endlessly [148].

\subsection{Influence of reactive oxygen species (ROS)}

The ROS is an oxygen-containing chemical group with high chemical reaction activities, mainly those involving the peroxide anion-free radical $\left(\mathrm{O}_{2}^{-}\right)$and the hydroxy radical $(\mathrm{OH})$. By causing lipid oxidation, it can increase mucosa permeability, further enhance phagocyte activity, generate more ROS and finally cause histiocyte injury. Scott et al. [149] demonstrated that in the pathological state, excessive ROS can cause tissue and cell injury. ROS can also participate in the formation of acute pancreatitis pancreatic edema and, possibly, in pancreatic necrosis and mediate leukocytes and platelets activated by TNF- $a$ in all organs to

\subsection{Toll-like receptor-4 (TLR4)}

In the early stage, acute pancreatitis mainly manifests as a chemical inflammation, which is a pancreatic nonspecific inflammatory process resulting from the action of a variety of factors. This inflammatory process is an inflammatory cascade reaction dominated by the body's innate immune system. Toll-like receptors are a kind of protein that can trigger this inflammatory cascade reaction. It is currently thought that TLRs might play a central role in the recognition of endogenous or exogenous antigen in the immune system and in the initiation of signal transduction in the process of inflammatory reaction during acute pancreatitis. Therefore, investigating the tissue-specific expression of TLRs (mainly TLR4) in pancreas and exploring their roles have great significance for understanding the pathogenesis of acute pancreatitis. A report has indicated that in the early stage of acute pancreatitis, the expression levels of TLR4, TNF- $\alpha$, and IL-6 in pancreas of acute pancreatitis patients are significantly higher than those in the control ones, the level of plasma TNF- $\alpha$ in acute pancreatitis patients increases subsequently, and the increase of plasma TNF-a level is positively correlated with the expression of TLR4, suggesting that the up-regulation of TLR4 expression on the surface of peripheral blood monocytes in patients with early acute pancreatitis might be associated with the activation of the innate immune system in the early stage of the disease [150]. Results of animal experiments have shown that TLR4 messenger RNA is also up-regulated in the pancreas of rats with cerulein-induced edematous pancreatitis in the early stage, the serum levels of cytokines such as TNF-a are subsequently elevated, and the two phenomena are correlated [151]. 
Some researchers believe that TLR4 may play an important role in the synthesis and release of pro-inflammatory cytokines, and the up-regulation of the TLR4 gene may be related with the development and progression of organ injury during acute pancreatitis $[152,153]$. Some studies have indicated that when severe acute pancreatitis is stimulated by LPS, the expressions of cytokines and cell adhesion molecules are significantly up-regulated in pancreas, thereby promoting the accumulation of excessive neutrophils in inflammatory region and leading to the injury of pancreas and other organs [154, 155]. Although it has been known that the translocation of intestinal bacteria and endotoxins is a key to secondary bacterial infection in necrotic pancreatic tissue, the mechanism of how multiple organ failure develops during pancreatitis has not yet been fully clarified [156].

\section{Conclusions}

Recent advances in experimental research have helped witness the pathophysiology of acute pancreatitis. The phenomena of microcirculatory changes observed in acute experimental pancreatitis during the past few years gradually underlie the disturbance of the local microcirculation in acute pancreatitis, but several challenges remain. Still some questions remain unexplained concerning the mechanisms: (1) Which is the first event in the pathogenesis of acute pancreatitis? (2) Which factor determines the edematous or necrotizing pancreatitis in a given experimental or clinical situation? (3) What is the role of impaired distribution of blood supply in early steps of acute pancreatitis? The potential mediators responsible for the progression of the disease severity and suggestions for therapeutic intervention have largely remained subjecting to speculation and debate.

Further research may help to find sufficient therapeutic approaches, eventually by affecting microcirculatory mechanisms, to influence development and progression of this disease.

\section{References}

[1] Mithofer K, Fernandez-del CC, Frick TW, Foitzik T, Bassi DG, Lewandrowski KB et al. Increased intrapancreatic trypsinogen activation in ischemia-induced experimental pancreatitis. Ann Surg 1995;221: 364-371.

[2] Menger MD, Bonkhoff $\mathrm{H}$, Vollmar B. Ischemia-reperfusion-induced pancreatic microvascular injury. An intravital fluorescence microscopic study in rats. Dig Dis Sci 1996;41: 823-830.

[3] Kusterer K, Poschmann T, Friedemann A, Enghofer M, Zendler S, Usadel KH. Arterial constriction, ischemia-reperfusion, and leukocyte adherence in acute pancreatitis. Am J Physiol 1993;265: G165-G171.

[4] Mayer H, Schmidt J, Thies J, Ryschich E, Gebhard MM, Herfarth C et al. Characterization and reduction of ischemia/reperfusion injury after experimental pancreas transplantation. J Gastrointest Surg 1999;3: 162-166.

[5] Vollmar B, Preissler G, Menger MD. Hemorrhagic hypotension induces arteriolar vasomotion and intermittent capillary perfusion in rat pancreas. Am J Physiol 1994;267: H1936-H1940.

[6] Klar E, Schratt W, Foitzik T, Buhr H, Herfarth C, Messmer K. Impact of microcirculatory flow pattern changes on the development of acute edematous and necrotizing pancreatitis in rabbit pancreas. Dig Dis Sci 1994;39: 2639-2644. 
[7] Hackert T, Pfeil D, Hartwig W, Gebhard MM, Buchler MW, Werner J. Platelet function in acute experimental pancreatitis induced by ischaemia-reperfusion. Br J Surg 2005;92: 724-728.

[8] Zhou ZG, Gao XH. Morphology of pancreatic microcirculation in the monkey: light and scanning electron microscopic study. Clin Anat 1995;8: 190-201.

[9] Zhou Z, Zeng Y, Yang P, Cheng Z, Zhao J, Shu Y et al. [Structure and function of pancreatic microcirculation]. Sheng Wu Yi Xue Gong Cheng Xue Za Zhi 2001;18: 195-200.

[10] von DE, Bleiziffer O, Pahernik S, Dellian M, Hoffmann T, Messmer K. Soluble complement receptor 1 preserves endothelial barrier function and microcirculation in postischemic pancreatitis in the rat. Am J Physiol Gastrointest Liver Physiol 2004;286: G791-G796.

[11] Zhou ZG, Chen YD. Influencing factors of pancreatic microcirculatory impairment in acute panceatitis. World J Gastroenterol 2002;8: 406-412.

[12] Vinten-Johansen J. Involvement of neutrophils in the pathogenesis of lethal myocardial reperfusion injury. Cardiovasc Res 2004;61: 481-497.

[13] Gourdin MJ, Bree B, De KM. The impact of ischaemia-reperfusion on the blood vessel. Eur J Anaesthesiol 2009;26: 537-547.

[14] Sluiter W, Pietersma A, Lamers JM, Koster JF. Leukocyte adhesion molecules on the vascular endothelium: their role in the pathogenesis of cardiovascular disease and the mechanisms underlying their expression. J Cardiovasc Pharmacol 1993;22 Suppl 4: S37-S44.

[15] Hidalgo A, Peired AJ, Wild MK, Vestweber D, Frenette PS. Complete identification of E-selectin ligands on neutrophils reveals distinct functions of PSGL-1, ESL-1, and CD44. Immunity 2007;26: 477-489.

[16] Gu Q, Yang XP, Bonde P, DiPaula A, Fox-Talbot K, Becker LC. Inhibition of TNF-alpha reduces myocardial injury and proinflammatory pathways following ischemiareperfusion in the dog. J Cardiovasc Pharmacol 2006;48: 320-328.

[17] Granger DN, Senchenkova E. 2010.

[18] Rodrigues SF, Granger DN. Role of blood cells in ischaemia-reperfusion induced endothelial barrier failure. Cardiovasc Res 2010;87: 291-299.

[19] Alexander JS, Alexander BC, Eppihimer LA, Goodyear N, Haque R, Davis CP et al. Inflammatory mediators induce sequestration of VE-cadherin in cultured human endothelial cells. Inflammation 2000;24: 99-113.

[20] Allingham MJ, van Buul JD, Burridge K. ICAM-1-mediated, Src- and Pyk2-dependent vascular endothelial cadherin tyrosine phosphorylation is required for leukocyte transendothelial migration. J Immunol 2007;179: 4053-4064.

[21] Flores NA, Goulielmos NV, Seghatchian MJ, Sheridan DJ. Myocardial ischaemia induces platelet activation with adverse electrophysiological and arrhythmogenic effects. Cardiovasc Res 1994;28: 1662-1671.

[22] Okada Y, Marchevsky AM, Zuo XJ, Pass JA, Kass RM, Matloff JM et al. Accumulation of platelets in rat syngeneic lung transplants: a potential factor responsible for preservation-reperfusion injury. Transplantation 1997;64: 801-806.

[23] Kuroda T, Shiohara E, Homma T, Furukawa Y, Chiba S. Effects of leukocyte and platelet depletion on ischemia--reperfusion injury to dog pancreas. Gastroenterology 1994;107: 1125-1134. 
[24] Weyrich AS, Elstad MR, McEver RP, McIntyre TM, Moore KL, Morrissey JH et al. Activated platelets signal chemokine synthesis by human monocytes. J Clin Invest 1996;97: 1525-1534.

[25] Khandoga A, Biberthaler P, Messmer K, Krombach F. Platelet-endothelial cell interactions during hepatic ischemia-reperfusion in vivo: a systematic analysis. Microvasc Res 2003;65: 71-77.

[26] Yeo EL, Sheppard JA, Feuerstein IA. Role of P-selectin and leukocyte activation in polymorphonuclear cell adhesion to surface adherent activated platelets under physiologic shear conditions (an injury vessel wall model). Blood 1994;83: 24982507.

[27] Kuijper PH, Gallardo Torres HI, Lammers JW, Sixma JJ, Koenderman L, Zwaginga JJ. Platelet and fibrin deposition at the damaged vessel wall: cooperative substrates for neutrophil adhesion under flow conditions. Blood 1997;89: 166-175.

[28] Salter JW, Krieglstein CF, Issekutz AC, Granger DN. Platelets modulate ischemia/reperfusion-induced leukocyte recruitment in the mesenteric circulation. Am J Physiol Gastrointest Liver Physiol 2001;281: G1432-G1439.

[29] Shebuski RJ, Kilgore KS. Role of inflammatory mediators in thrombogenesis. J Pharmacol Exp Ther 2002;300: 729-735.

[30] Bouchard BA, Tracy PB. Platelets, leukocytes, and coagulation. Curr Opin Hematol 2001;8: 263-269.

[31] Yokoyama S, Ikeda H, Haramaki N, Yasukawa H, Murohara T, Imaizumi T. Platelet Pselectin plays an important role in arterial thrombogenesis by forming large stable platelet-leukocyte aggregates. J Am Coll Cardiol 2005;45: 1280-1286.

[32] Dole VS, Bergmeier W, Mitchell HA, Eichenberger SC, Wagner DD. Activated platelets induce Weibel-Palade-body secretion and leukocyte rolling in vivo: role of Pselectin. Blood 2005;106: 2334-2339.

[33] Martin M, Mory C, Prescher A, Wittekind C, Fiedler M, Uhlmann D. Protective effects of early $\mathrm{CD} 4(+) \mathrm{T}$ cell reduction in hepatic ischemia/reperfusion injury. J Gastrointest Surg 2010;14: 511-519.

[34] Matsuda T, Yamaguchi Y, Matsumura F, Akizuki E, Okabe K, Liang J et al. Immunosuppressants decrease neutrophil chemoattractant and attenuate ischemia/reperfusion injury of the liver in rats. J Trauma 1998;44: 475-484.

[35] Le MO, Louis H, Demols A, Desalle F, Demoor F, Quertinmont E et al. Cold liver ischemia-reperfusion injury critically depends on liver $\mathrm{T}$ cells and is improved by donor pretreatment with interleukin 10 in mice. Hepatology 2000;31: 1266-1274.

[36] Martin M, Mory C, Prescher A, Wittekind C, Fiedler M, Uhlmann D. Protective effects of early $\mathrm{CD} 4(+) \mathrm{T}$ cell reduction in hepatic ischemia/reperfusion injury. J Gastrointest Surg 2010;14: 511-519.

[37] Takada M, Chandraker A, Nadeau KC, Sayegh MH, Tilney NL. The role of the B7 costimulatory pathway in experimental cold ischemia/reperfusion injury. J Clin Invest 1997;100: 1199-1203.

[38] Zwacka RM, Zhang Y, Halldorson J, Schlossberg H, Dudus L, Engelhardt JF. CD4(+) Tlymphocytes mediate ischemia/reperfusion-induced inflammatory responses in mouse liver. J Clin Invest 1997;100: 279-289. 
[39] Suzuki S, Toledo-Pereyra LH, Rodriguez FJ, Cejalvo D. Neutrophil infiltration as an important factor in liver ischemia and reperfusion injury. Modulating effects of FK506 and cyclosporine. Transplantation 1993;55: 1265-1272.

[40] Matsuda T, Yamaguchi Y, Matsumura F, Akizuki E, Okabe K, Liang J et al. Immunosuppressants decrease neutrophil chemoattractant and attenuate ischemia/reperfusion injury of the liver in rats. J Trauma 1998;44: 475-484.

[41] Shen XD, Ke B, Zhai Y, Gao F, Anselmo D, Lassman CR et al. Stat4 and Stat6 signaling in hepatic ischemia/reperfusion injury in mice: HO-1 dependence of Stat4 disruption-mediated cytoprotection. Hepatology 2003;37: 296-303.

[42] Shen XD, Ke B, Zhai Y, Amersi F, Gao F, Anselmo DM et al. CD154-CD40 T-cell costimulation pathway is required in the mechanism of hepatic ischemia/reperfusion injury, and its blockade facilitates and depends on heme oxygenase-1 mediated cytoprotection. Transplantation 2002;74: 315-319.

[43] Anselmo DM, Amersi FF, Shen XD, Gao F, Katori M, Lassman C et al. FTY720 pretreatment reduces warm hepatic ischemia reperfusion injury through inhibition of T-lymphocyte infiltration. Am J Transplant 2002;2: 843-849.

[44] Clavien PA, Harvey PR, Sanabria JR, Cywes R, Levy GA, Strasberg SM. Lymphocyte adherence in the reperfused rat liver: mechanisms and effects. Hepatology 1993;17: 131-142.

[45] Bella J, Kolatkar PR, Marlor CW, Greve JM, Rossmann MG. The structure of the two amino-terminal domains of human intercellular adhesion molecule-1 suggests how it functions as a rhinovirus receptor. Virus Res 1999;62: 107-117.

[46] Sun W, Watanabe Y, Wang ZQ. Expression and significance of ICAM-1 and its counter receptors LFA-1 and Mac- 1 in experimental acute pancreatitis of rats. World J Gastroenterol 2006;12: 5005-5009.

[47] Liu XM, Liu QG, Xu J, Pan CE. Microcirculation disturbance affects rats with acute severe pancreatitis following lung injury. World J Gastroenterol 2005;11: 6208-6211.

[48] Steer ML. Relationship between pancreatitis and lung diseases. Respir Physiol 2001;128: 13-16.

[49] Hartwig W, Werner J, Warshaw AL, Antoniu B, Castillo CF, Gebhard MM et al. Membrane-bound ICAM-1 is upregulated by trypsin and contributes to leukocyte migration in acute pancreatitis. Am J Physiol Gastrointest Liver Physiol 2004;287: G1194-G1199.

[50] Keck T, Friebe V, Warshaw AL, Antoniu BA, Waneck G, Benz S et al. Pancreatic proteases in serum induce leukocyte-endothelial adhesion and pancreatic microcirculatory failure. Pancreatology 2005;5: 241-250.

[51] Werner J, Z'graggen K, Fernandez-del CC, Lewandrowski KB, Compton CC, Warshaw AL. Specific therapy for local and systemic complications of acute pancreatitis with monoclonal antibodies against ICAM-1. Ann Surg 1999;229: 834-840.

[52] Khandoga A, Biberthaler P, Enders G, Axmann S, Hutter J, Messmer K et al. Platelet adhesion mediated by fibrinogen-intercelllular adhesion molecule- 1 binding induces tissue injury in the postischemic liver in vivo. Transplantation 2002;74: 681688.

[53] Gao HK, Zhou ZG, Chen YQ, Han FH, Wang C. Expression of platelet endothelial cell adhesion molecule-1 between pancreatic microcirculation and peripheral 
circulation in rats with acute edematous pancreatitis. Hepatobiliary Pancreat Dis Int 2003;2: 463-466.

[54] Gao HK, Zhou ZG, Han FH, Chen YQ, Yan WW, He T et al. Differences in platelet endothelial cell adhesion molecule-1 expression between peripheral circulation and pancreatic microcirculation in cerulein-induced acute edematous pancreatitis. World J Gastroenterol 2005;11: 661-664.

[55] Eppihimer MJ, Wolitzky B, Anderson DC, Labow MA, Granger DN. Heterogeneity of expression of E- and P-selectins in vivo. Circ Res 1996;79: 560-569.

[56] Massberg S, Enders G, Leiderer R, Eisenmenger S, Vestweber D, Krombach F et al. Platelet-endothelial cell interactions during ischemia/reperfusion: the role of Pselectin. Blood 1998;92: 507-515.

[57] Cooper D, Chitman KD, Williams MC, Granger DN. Time-dependent platelet-vessel wall interactions induced by intestinal ischemia-reperfusion. Am J Physiol Gastrointest Liver Physiol 2003;284: G1027-G1033.

[58] Nishijima K, Kiryu J, Tsujikawa A, Honjo M, Nonaka A, Yamashiro K et al. In vivo evaluation of platelet--endothelial interactions after transient retinal ischemia. Invest Ophthalmol Vis Sci 2001;42: 2102-2109.

[59] Katayama T, Ikeda $Y$, Handa M, Tamatani T, Sakamoto S, Ito $M$ et al. Immunoneutralization of glycoprotein Ibalpha attenuates endotoxin-induced interactions of platelets and leukocytes with rat venular endothelium in vivo. Circ Res 2000;86: 1031-1037.

[60] Gong Z, Yuan Y, Lou K, Tu S, Zhai Z, Xu J. Mechanisms of Chinese herb emodin and somatostatin analogs on pancreatic regeneration in acute pancreatitis in rats. Pancreas 2002;25: 154-160.

[61] Frenette PS, Denis CV, Weiss L, Jurk K, Subbarao S, Kehrel B et al. P-Selectin glycoprotein ligand 1 (PSGL-1) is expressed on platelets and can mediate plateletendothelial interactions in vivo. J Exp Med 2000;191: 1413-1422.

[62] Andre P, Denis CV, Ware J, Saffaripour S, Hynes RO, Ruggeri ZM et al. Platelets adhere to and translocate on von Willebrand factor presented by endothelium in stimulated veins. Blood 2000;96: 3322-3328.

[63] Romo GM, Dong JF, Schade AJ, Gardiner EE, Kansas GS, Li CQ et al. The glycoprotein Ib-IX-V complex is a platelet counterreceptor for P-selectin. J Exp Med 1999;190: 803-814.

[64] Luscher TF, Oemar BS, Boulanger CM, Hahn AW. Molecular and cellular biology of endothelin and its receptors--Part I. J Hypertens 1993;11: 7-11.

[65] McMillen MA, Huribal M, Cunningham ME, Kumar R, Sumpio BE. Endothelin-1 increases intracellular calcium in human monocytes and causes production of interleukin-6. Crit Care Med 1995;23: 34-40.

[66] Filep JG, Clozel M, Fournier A, Foldes-Filep E. Characterization of receptors mediating vascular responses to endothelin-1 in the conscious rat. Br J Pharmacol 1994;113: 845-852.

[67] Spiegel HU, Scommotau S, Uhlmann D, Giersch B. Effect of the endothelin receptor antagonist bosentan on postischemic liver microcirculation. Zentralbl Chir 1996;121: 788-793. 
[68] McMillen MA, Huribal M, Kumar R, Sumpio BE. Endothelin-stimulated human monocytes produce prostaglandin E2 but not leukotriene B4. J Surg Res 1993;54: 331-335.

[69] Deacon K, Knox AJ. Endothelin-1 (ET-1) increases the expression of remodeling genes in vascular smooth muscle through linked calcium and cAMP pathways: role of a phospholipase $\mathrm{A}(2)(\mathrm{cPLA}(2)) /$ cyclooxygenase-2 (COX-2)/prostacyclin receptordependent autocrine loop. J Biol Chem 2010;285: 25913-25927.

[70] Ishida K, Takeshige K, Minakami S. Endothelin-1 enhances superoxide generation of human neutrophils stimulated by the chemotactic peptide $\mathrm{N}$-formyl-methionylleucyl-phenylalanine. Biochem Biophys Res Commun 1990;173: 496-500.

[71] Bauer M, Zhang JX, Bauer I, Clemens MG. ET-1 induced alterations of hepatic microcirculation: sinusoidal and extrasinusoidal sites of action. Am J Physiol 1994;267: G143-G149.

[72] Lopez FA, Riesco A, Espinosa G, Digiuni E, Cernadas MR, Alvarez V et al. Effect of endothelin-1 on neutrophil adhesion to endothelial cells and perfused heart. Circulation 1993;88: 1166-1171.

[73] Yanagisawa M, Masaki T. Molecular biology and biochemistry of the endothelins. Trends Pharmacol Sci 1989;10: 374-378.

[74] Eibl G, Hotz HG, Faulhaber J, Kirchengast M, Buhr HJ, Foitzik T. Effect of endothelin and endothelin receptor blockade on capillary permeability in experimental pancreatitis. Gut 2000;46: 390-394.

[75] Takaori K, Inoue K, Kogire M, Higashide S, Tun T, Aung T et al. Effects of endothelin on microcirculation of the pancreas. Life Sci 1992;51: 615-622.

[76] Hildebrand P, Mrozinski JE, Jr., Mantey SA, Patto RJ, Jensen RT. Pancreatic acini possess endothelin receptors whose internalization is regulated by PLC-activating agents. Am J Physiol 1993;264: G984-G993.

[77] Hof RP, Hof A, Takiguchi Y. Massive regional differences in the vascular effects of endothelin. J Hypertens Suppl 1989;7: S274-S275.

[78] Foitzik T, Hotz HG, Hot B, Kirchengast M, Buhr HJ. Endothelin-1 mediates the alcoholinduced reduction of pancreatic capillary blood flow. J Gastrointest Surg 1998;2: 379-384.

[79] Foitzik T, Faulhaber J, Hotz HG, Kirchengast M, Buhr HJ. Endothelin receptor blockade improves fluid sequestration, pancreatic capillary blood flow, and survival in severe experimental pancreatitis. Ann Surg 1998;228: 670-675.

[80] Plusczyk T, Bersal B, Westermann S, Menger M, Feifel G. ET-1 induces pancreatitis-like microvascular deterioration and acinar cell injury. J Surg Res 1999;85: 301-310.

[81] Lehoux S, Plante GE, Sirois MG, Sirois P, Orleans-Juste P. Phosphoramidon blocks bigendothelin-1 but not endothelin-1 enhancement of vascular permeability in the rat. Br J Pharmacol 1992;107: 996-1000.

[82] Palmer RM, Ferrige AG, Moncada S. Nitric oxide release accounts for the biological activity of endothelium-derived relaxing factor. Nature 1987;327: 524-526.

[83] Masamune A, Shimosegawa T, Satoh A, Fujita M, Sakai Y, Toyota T. Nitric oxide decreases endothelial activation by rat experimental severe pancreatitis-associated ascitic fluids. Pancreas 2000;20: 297-304.

[84] Kubes P, Kanwar S, Niu XF, Gaboury JP. Nitric oxide synthesis inhibition induces leukocyte adhesion via superoxide and mast cells. FASEB J 1993;7: 1293-1299. 
[85] Kubes P, Suzuki M, Granger DN. Nitric oxide: an endogenous modulator of leukocyte adhesion. Proc Natl Acad Sci U S A 1991;88: 4651-4655.

[86] Moncada S, Higgs A. The L-arginine-nitric oxide pathway. N Engl J Med 1993;329: 2002-2012.

[87] Niu XF, Smith CW, Kubes P. Intracellular oxidative stress induced by nitric oxide synthesis inhibition increases endothelial cell adhesion to neutrophils. Circ Res 1994;74: 1133-1140.

[88] Rubanyi GM, Ho EH, Cantor EH, Lumma WC, Botelho LH. Cytoprotective function of nitric oxide: inactivation of superoxide radicals produced by human leukocytes. Biochem Biophys Res Commun 1991;181: 1392-1397.

[89] Beckman JS, Crow JP. Pathological implications of nitric oxide, superoxide and peroxynitrite formation. Biochem Soc Trans 1993;21: 330-334.

[90] Lipsett PA. Serum cytokines, proteins, and receptors in acute pancreatitis: mediators, markers, or more of the same? Crit Care Med 2001;29: 1642-1644.

[91] Hirota M, Nozawa F, Okabe A, Shibata M, Beppu T, Shimada S et al. Relationship between plasma cytokine concentration and multiple organ failure in patients with acute pancreatitis. Pancreas 2000;21: 141-146.

[92] de D, I, Perez M, de La MA, Sevillano S, Orfao A, Ramudo L et al. Contribution of circulating leukocytes to cytokine production in pancreatic duct obstructioninduced acute pancreatitis in rats. Cytokine 2002;20: 295-303.

[93] Descamps FJ, Van den Steen PE, Martens E, Ballaux F, Geboes K, Opdenakker G. Gelatinase $B$ is diabetogenic in acute and chronic pancreatitis by cleaving insulin. FASEB J 2003;17: 887-889.

[94] Ammori BJ. Role of the gut in the course of severe acute pancreatitis. Pancreas 2003;26: 122-129.

[95] Cassatella MA. The production of cytokines by polymorphonuclear neutrophils. Immunol Today 1995;16: 21-26.

[96] Ogawa M. Acute pancreatitis and cytokines: "second attack" by septic complication leads to organ failure. Pancreas 1998;16: 312-315.

[97] Hughes CB, Gaber LW, Mohey el-Din AB, Grewal HP, Kotb M, Mann L et al. Inhibition of TNF alpha improves survival in an experimental model of acute pancreatitis. Am Surg 1996;62: 8-13.

[98] Zhang XP, Wang L, Zhou YF. The pathogenic mechanism of severe acute pancreatitis complicated with renal injury: a review of current knowledge. Dig Dis Sci 2008;53: 297-306.

[99] Pohlman TH, Stanness KA, Beatty PG, Ochs HD, Harlan JM. An endothelial cell surface factor(s) induced in vitro by lipopolysaccharide, interleukin 1, and tumor necrosis factor-alpha increases neutrophil adherence by a CDw18-dependent mechanism. J Immunol 1986;136: 4548-4553.

[100] Norman JG, Franz MG, Fink GS, Messina J, Fabri PJ, Gower WR et al. Decreased mortality of severe acute pancreatitis after proximal cytokine blockade. Ann Surg 1995;221: 625-631.

[101] Norman JG, Fink G, Franz M, Guffey J, Carter G, Davison B et al. Active interleukin-1 receptor required for maximal progression of acute pancreatitis. Ann Surg 1996;223: 163-169. 
[102] Fink G, Yang J, Carter G, Norman J. Acute pancreatitis-induced enzyme release and necrosis are attenuated by IL-1 antagonism through an indirect mechanism. J Surg Res 1997;67: 94-97.

[103] Kusske AM, Rongione AJ, Reber HA. Cytokines and acute pancreatitis. Gastroenterology 1996;110: 639-642.

[104] Lentz SR, Tsiang M, Sadler JE. Regulation of thrombomodulin by tumor necrosis factor-alpha: comparison of transcriptional and posttranscriptional mechanisms. Blood 1991;77: 542-550.

[105] Gross V, Andreesen R, Leser HG, Ceska M, Liehl E, Lausen M et al. Interleukin-8 and neutrophil activation in acute pancreatitis. Eur J Clin Invest 1992;22: 200-203.

[106] Kimura Y, Torimura T, Ueno T, Inuzuka S, Tanikawa K. Transforming growth factor beta 1, extracellular matrix, and inflammatory cells in wound repair using a closed duodenal loop pancreatitis model rat. Immunohistochemical study. Scand J Gastroenterol 1995;30: 707-714.

[107] Konturek PC, Dembinski A, Warzecha Z, Ceranowicz P, Konturek SJ, Stachura J et al. Expression of transforming growth factor-beta 1 and epidermal growth factor in caerulein-induced pancreatitis in rat. J Physiol Pharmacol 1997;48: 59-72.

[108] Rongione AJ, Kusske AM, Kwan K, Ashley SW, Reber HA, McFadden DW. Interleukin 10 reduces the severity of acute pancreatitis in rats. Gastroenterology 1997;112: 960967.

[109] Kusske AM, Rongione AJ, Ashley SW, McFadden DW, Reber HA. Interleukin-10 prevents death in lethal necrotizing pancreatitis in mice. Surgery 1996;120: 284-288.

[110] Bhatia M. Acute pancreatitis as a model of SIRS. Front Biosci 2009;14: 2042-2050.

[111] Johnson CD, Kingsnorth AN, Imrie CW, McMahon MJ, Neoptolemos JP, McKay C et al. Double blind, randomised, placebo controlled study of a platelet activating factor antagonist, lexipafant, in the treatment and prevention of organ failure in predicted severe acute pancreatitis. Gut 2001;48: 62-69.

[112] Eltzschig HK, Collard CD. Vascular ischaemia and reperfusion injury. Br Med Bull 2004;70: 71-86.

[113] Arumugam TV, Magnus T, Woodruff TM, Proctor LM, Shiels IA, Taylor SM. Complement mediators in ischemia-reperfusion injury. Clin Chim Acta 2006;374: 33-45.

[114] Thrane AS, Skehan JD, Thrane PS. A novel interpretation of immune redundancy and duality in reperfusion injury with important implications for intervention in ischaemic disease. Med Hypotheses 2007;68: 1363-1370.

[115] Lechin F, van der DB. Platelet aggregation, platelet serotonin and pancreatitis. JOP 2004;5: 237-238.

[116] Barradas MA, Mikhailidis DP. Serotonin, histamine and platelets in vascular disease with special reference to peripheral vascular disease. Braz J Med Biol Res 1992;25: 1063-1076.

[117] Prinz RA, Fareed J, Rock A, Squillaci G, Wallenga J. Platelet activation by human pancreatic fluid. J Surg Res 1984;37: 314-319.

[118] Yoshino T, Yamaguchi I. Possible involvement of 5-HT2 receptor activation in aggravation of diet-induced acute pancreatitis in mice. J Pharmacol Exp Ther 1997;283: 1495-1502. 
[119] de CF, David JL, Janssen PA. Inhibition of 5-hydroxytryptamine-induced and amplified human platelet aggregation by ketanserin ( $\mathrm{R} 41,468)$, a selective 5-HT2receptor antagonist. 1982. Agents Actions 1994;43: 225-234.

[120] Marcus AJ. Recent progress in the role of platelets in occlusive vascular disease. Stroke 1983;14: 475-479.

[121] Gobbi G, Mirandola P, Tazzari PL, Ricci F, Caimi L, Cacchioli A et al. Flow cytometry detection of serotonin content and release in resting and activated platelets. Br J Haematol 2003;121: 892-896.

[122] Bagate K, Grima M, Imbs JL, Jong WD, Helwig JJ, Barthelmebs M. Signal transduction pathways involved in kinin B(2) receptor-mediated vasodilation in the rat isolated perfused kidney. Br J Pharmacol 2001;132: 1735-1742.

[123] Fleming I, Bauersachs J, Busse R. Paracrine functions of the coronary vascular endothelium. Mol Cell Biochem 1996;157: 137-145.

[124] Fulton D, Mahboubi K, McGiff JC, Quilley J. Cytochrome P450-dependent effects of bradykinin in the rat heart. Br J Pharmacol 1995;114: 99-102.

[125] Abbott NJ. Inflammatory mediators and modulation of blood-brain barrier permeability. Cell Mol Neurobiol 2000;20: 131-147.

[126] Feletou M, Bonnardel E, Canet E. Bradykinin and changes in microvascular permeability in the hamster cheek pouch: role of nitric oxide. Br J Pharmacol 1996;118: 1371-1376.

[127] Sato E, Koyama S, Nomura H, Kubo K, Sekiguchi M. Bradykinin stimulates alveolar macrophages to release neutrophil, monocyte, and eosinophil chemotactic activity. J Immunol 1996;157: 3122-3129.

[128] Schuschke DA, Saari JT, Miller FN. Leukocyte-endothelial adhesion is impaired in the cremaster muscle microcirculation of the copper-deficient rat. Immunol Lett 2001;76: 139-144.

[129] Shigematsu S, Ishida S, Gute DC, Korthuis RJ. Concentration-dependent effects of bradykinin on leukocyte recruitment and venular hemodynamics in rat mesentery. Am J Physiol 1999;277: H152-H160.

[130] Mao E, Zhang S, Han T. [Pancreatic ischemia: a continuous injury factor in acute necrotic pancreatitis]. Zhonghua Wai Ke Za Zhi 1997;35: 150-152.

[131] Motoyoshi M, Sugiyama M, Atomi Y, Kimura W, Nagawa H. Effect of a selective thromboxane A2 synthetase inhibitor on the systemic changes induced by circulating pancreatic phospholipase A2. J Gastroenterol 2006;41: 1094-1098.

[132] Hoffmann TF, Leiderer R, Waldner H, Messmer K. Bradykinin antagonists HOE-140 and CP-0597 diminish microcirculatory injury after ischaemia-reperfusion of the pancreas in rats. Br J Surg 1996;83: 189-195.

[133] Shi C, Andersson R, Zhao X, Wang X. Potential role of reactive oxygen species in pancreatitis-associated multiple organ dysfunction. Pancreatology 2005;5: 492-500.

[134] Smith WL, DeWitt DL, Garavito RM. Cyclooxygenases: structural, cellular, and molecular biology. Annu Rev Biochem 2000;69: 145-182.

[135] Warzecha Z, Dembinski A, Ceranowicz P, Konturek SJ, Dembinski M, Pawlik WW et al. Ischemic preconditioning inhibits development of edematous cerulein-induced pancreatitis: involvement of cyclooxygenases and heat shock protein 70. World J Gastroenterol 2005;11: 5958-5965. 
[136] Song AM, Bhagat L, Singh VP, Van Acker GG, Steer ML, Saluja AK. Inhibition of cyclooxygenase-2 ameliorates the severity of pancreatitis and associated lung injury. Am J Physiol Gastrointest Liver Physiol 2002;283: G1166-G1174.

[137] Ethridge RT, Chung DH, Slogoff M, Ehlers RA, Hellmich MR, Rajaraman S et al. Cyclooxygenase-2 gene disruption attenuates the severity of acute pancreatitis and pancreatitis-associated lung injury. Gastroenterology 2002;123: 1311-1322.

[138] Foitzik T, Hotz HG, Hotz B, Wittig F, Buhr HJ. Selective inhibition of cyclooxygenase-2 (COX-2) reduces prostaglandin E2 production and attenuates systemic disease sequelae in experimental pancreatitis. Hepatogastroenterology 2003;50: 1159-1162.

[139] Dobosz M, Wajda Z, Hac S, Mysliwska J, Bryl E, Mionskowska L et al. Nitric oxide, heparin and procaine treatment in experimental ceruleine-induced acute pancreatitis in rats. Arch Immunol Ther Exp (Warsz ) 1999;47: 155-160.

[140] Yucel K, Alhan E, Kucuktulu U, Piri M, Ercin C, Deger O. The effects of prostaglandin $\mathrm{E} 1$ on the microperfusion of the pancreas during acute necrotizing pancreatitis in rats. Hepatogastroenterology 2002;49: 544-548.

[141] Gukovsky I, Gukovskaya AS, Blinman TA, Zaninovic V, Pandol SJ. Early NF-kappaB activation is associated with hormone-induced pancreatitis. Am J Physiol 1998;275: G1402-G1414.

[142] Shi C, Zhao X, Wang X, Andersson R. Role of nuclear factor-kappaB, reactive oxygen species and cellular signaling in the early phase of acute pancreatitis. Scand J Gastroenterol 2005;40: 103-108.

[143] Bates DO, Lodwick D, Williams B. Vascular endothelial growth factor and microvascular permeability. Microcirculation 1999;6: 83-96.

[144] Gray MJ, Zhang J, Ellis LM, Semenza GL, Evans DB, Watowich SS et al. HIF-1alpha, STAT3, CBP/p300 and Ref-1/APE are components of a transcriptional complex that regulates Src-dependent hypoxia-induced expression of VEGF in pancreatic and prostate carcinomas. Oncogene 2005;24: 3110-3120.

[145] Warzecha Z, Dembinski A, Ceranowicz P, Dembinski M, Kownacki P, Konturek SJ et al. Immunohistochemical expression of FGF-2, PDGF-A, VEGF and TGF beta RII in the pancreas in the course of ischemia/reperfusion-induced acute pancreatitis. J Physiol Pharmacol 2004;55: 791-810.

[146] von DE, Meyer S, Thorn D, Marme D, Hopt UT, Thomusch O. Targeting vascular endothelial growth factor pathway offers new possibilities to counteract microvascular disturbances during ischemia/reperfusion of the pancreas. Transplantation 2006;82: 543-549.

[147] Windsor JA, Fearon KC, Ross JA, Barclay GR, Smyth E, Poxton I et al. Role of serum endotoxin and antiendotoxin core antibody levels in predicting the development of multiple organ failure in acute pancreatitis. Br J Surg 1993;80: 1042-1046.

[148] Zhang XP, Zhang J, Song QL, Chen HQ. Mechanism of acute pancreatitis complicated with injury of intestinal mucosa barrier. J Zhejiang Univ Sci B 2007;8: 888-895.

[149] Scott P, Bruce C, Schofield D, Shiel N, Braganza JM, McCloy RF. Vitamin C status in patients with acute pancreatitis. Br J Surg 1993;80: 750-754.

[150] Li HG, Zhou ZG, Li Y, Zheng XL, Lei S, Zhu L et al. Alterations of Toll-like receptor 4 expression on peripheral blood monocytes during the early stage of human acute pancreatitis. Dig Dis Sci 2007;52: 1973-1978. 
[151] Li Y, Zhou ZG, Xia QJ, Zhang J, Li HG, Cao GQ et al. Toll-like receptor 4 detected in exocrine pancreas and the change of expression in cerulein-induced pancreatitis. Pancreas 2005;30: 375-381.

[152] Wu HS, Zhang L, Chen Y, Guo XJ, Wang L, Xu JB et al. Effect of nitric oxide on toll-like receptor 2 and 4 gene expression in rats with acute lung injury complicated by acute hemorrhage necrotizing pancreatitis. Hepatobiliary Pancreat Dis Int 2005;4: 609-613.

[153] Sharif R, Dawra R, Wasiluk K, Phillips P, Dudeja V, Kurt-Jones E et al. Impact of tolllike receptor 4 on the severity of acute pancreatitis and pancreatitis-associated lung injury in mice. Gut 2009;58: 813-819.

[154] Ueki M, Taie S, Chujo K, Asaga T, Iwanaga Y, Ono J et al. Urinary trypsin inhibitor reduces inflammatory response in kidney induced by lipopolysaccharide. J Biosci Bioeng 2007;104: 315-320.

[155] Vonlaufen A, Xu Z, Daniel B, Kumar RK, Pirola R, Wilson J et al. Bacterial endotoxin: a trigger factor for alcoholic pancreatitis? Evidence from a novel, physiologically relevant animal model. Gastroenterology 2007;133: 1293-1303.

[156] Yasuda T, Takeyama Y, Ueda T, Shinzeki M, Sawa H, Nakajima T et al. Breakdown of intestinal mucosa via accelerated apoptosis increases intestinal permeability in experimental severe acute pancreatitis. J Surg Res 2006;135: 18-26.

[157] Uhlmann D, Lauer H, Serr F, Witzigmann H. Pathophysiological role of platelets and platelet system in acute pancreatitis. Microvasc Res 2008;76: 114-123.

[158] Noto T, Furuichi Y, Ishiye M, Matsuoka N, Aramori I, Mutoh S et al. Tacrolimus (FK506) limits accumulation of granulocytes and platelets and protects against brain damage after transient focal cerebral ischemia in rat. Biol Pharm Bull 2007;30: 313-317.

[159] Khandoga A, Biberthaler P, Enders G, Teupser D, Axmann S, Luchting B et al. Pselectin mediates platelet-endothelial cell interactions and reperfusion injury in the mouse liver in vivo. Shock 2002;18: 529-535.

[160] Liu X, Xie W, Liu P, Duan M, Jia Z, Li W et al. Mechanism of the cardioprotection of rhEPO pretreatment on suppressing the inflammatory response in ischemiareperfusion. Life Sci 2006;78: 2255-2264.

[161] Contaldo C, Meier C, Elsherbiny A, Harder Y, Trentz O, Menger MD et al. Human recombinant erythropoietin protects the striated muscle microcirculation of the dorsal skinfold from postischemic injury in mice. Am J Physiol Heart Circ Physiol 2007;293: H274-H283.

[162] Zarbock A, Singbartl K, Ley K. Complete reversal of acid-induced acute lung injury by blocking of platelet-neutrophil aggregation. J Clin Invest 2006;116: 3211-3219.

[163] Prescher A, Mory C, Martin M, Fiedler M, Uhlmann D. Effect of FTY720 treatment on postischemic pancreatic microhemodynamics. Transplant Proc 2010;42: 3984-3985.

[164] Foitzik T, Eibl G, Buhr HJ. Therapy for microcirculatory disorders in severe acute pancreatitis: comparison of delayed therapy with ICAM-1 antibodies and a specific endothelin A receptor antagonist. J Gastrointest Surg 2000;4: 240-246.

[165] Frossard JL, Saluja A, Bhagat L, Lee HS, Bhatia M, Hofbauer B et al. The role of intercellular adhesion molecule 1 and neutrophils in acute pancreatitis and pancreatitis-associated lung injury. Gastroenterology 1999;116: 694-701. 
[166] Stangl V, Lorenz M, Ludwig A, Grimbo N, Guether C, Sanad W et al. The flavonoid phloretin suppresses stimulated expression of endothelial adhesion molecules and reduces activation of human platelets. J Nutr 2005;135: 172-178.

[167] Lau HY, Bhatia M. Effect of CP-96,345 on the expression of adhesion molecules in acute pancreatitis in mice. Am J Physiol Gastrointest Liver Physiol 2007;292: G1283G1292.

[168] Pruefer D, Makowski J, Schnell M, Buerke U, Dahm M, Oelert H et al. Simvastatin inhibits inflammatory properties of Staphylococcus aureus alpha-toxin. Circulation 2002;106: 2104-2110.

[169] Zhao JL, Yang YJ, Cui CJ, You SJ, Gao RL. Pretreatment with simvastatin reduces myocardial no-reflow by opening mitochondrial K(ATP) channel. Br J Pharmacol 2006;149: 243-249.

[170] Nomura S, Shouzu A, Omoto S, Nishikawa M, Fukuhara S, Iwasaka T. Losartan and simvastatin inhibit platelet activation in hypertensive patients. J Thromb Thrombolysis 2004;18: 177-185.

[171] Uhlmann D, Gaebel G, Armann B, Ludwig S, Hess J, Pietsch UC et al. Attenuation of proinflammatory gene expression and microcirculatory disturbances by endothelin A receptor blockade after orthotopic liver transplantation in pigs. Surgery 2006;139: 61-72.

[172] Uhlmann D, Gabel G, Ludwig S, Armann B, Hess J, Pietsch UC et al. Effects of ET(A) receptor antagonism on proinflammatory gene expression and microcirculation following hepatic ischemia/reperfusion. Microcirculation 2005;12: 405-419.

[173] Witzigmann H, Ludwig S, Armann B, Gabel G, Teupser D, Kratzsch J et al. Endothelin(A) receptor blockade reduces ischemia/reperfusion injury in pig pancreas transplantation. Ann Surg 2003;238: 264-274.

[174] Werner J, Rivera J, Fernandez-del CC, Lewandrowski K, Adrie C, Rattner DW et al. Differing roles of nitric oxide in the pathogenesis of acute edematous versus necrotizing pancreatitis. Surgery 1997;121: 23-30.

[175] Dobosz M, Hac S, Mionskowska L, Dobrowolski S, Wajda Z. Microcirculatory disturbances of the pancreas in cerulein-induced acute pancreatitis in rats with reference to L-arginine, heparin, and procaine treatment. Pharmacol Res 1997;36: 123-128.

[176] Vollmar B, Janata J, Yamauchi JI, Menger MD. Attenuation of microvascular reperfusion injury in rat pancreas transplantation by L-arginine. Transplantation 1999;67: 950-955.

[177] Christman JW, Sadikot RT, Blackwell TS. The role of nuclear factor-kappa B in pulmonary diseases. Chest 2000;117: 1482-1487.

[178] Orian A, Whiteside S, Israel A, Stancovski I, Schwartz AL, Ciechanover A. Ubiquitinmediated processing of NF-kappa B transcriptional activator precursor p105. Reconstitution of a cell-free system and identification of the ubiquitin-carrier protein, E2, and a novel ubiquitin-protein ligase, E3, involved in conjugation. J Biol Chem 1995;270: 21707-21714.

[179] Eibl G, Buhr HJ, Foitzik T. Therapy of microcirculatory disorders in severe acute pancreatitis: what mediators should we block? Intensive Care Med 2002;28: 139146. 
[180] Kingsnorth AN, Galloway SW, Formela LJ. Randomized, double-blind phase II trial of Lexipafant, a platelet-activating factor antagonist, in human acute pancreatitis. Br J Surg 1995;82: 1414-1420.

[181] Bloechle C, Kusterer K, Kuehn RM, Schneider C, Knoefel WT, Izbicki JR. Inhibition of bradykinin B2 receptor preserves microcirculation in experimental pancreatitis in rats. Am J Physiol 1998;274: G42-G51.

[182] Hirano T, Hirano K. Thromboxane A2 receptor antagonist prevents pancreatic microvascular leakage in rats with caerulein-induced acute pancreatitis. Int J Surg Investig 1999;1: 203-210.

[183] von Andrian UH, Mackay CR. T-cell function and migration. Two sides of the same coin. N Engl J Med 2000;343: 1020-1034.

[184] Pereda J, Sabater L, Aparisi L, Escobar J, Sandoval J, Vina J et al. Interaction between cytokines and oxidative stress in acute pancreatitis. Curr Med Chem 2006;13: 27752787. 


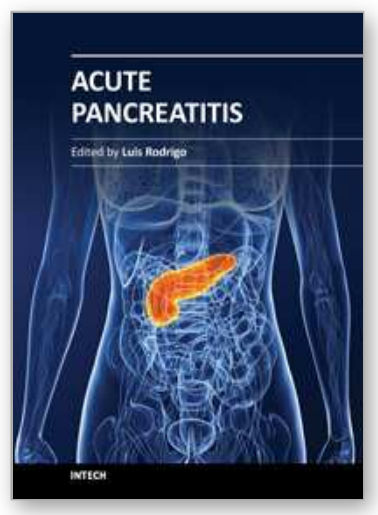

\author{
Acute Pancreatitis \\ Edited by Prof. Luis Rodrigo
}

ISBN 978-953-307-984-4

Hard cover, 300 pages

Publisher InTech

Published online 18, January, 2012

Published in print edition January, 2012

Acute Pancreatitis (AP) in approximately $80 \%$ of cases, occurs as a secondary complication related to gallstone disease and alcohol misuse. However there are several other different causes that produce it such as metabolism, genetics, autoimmunity, post-ERCP, and trauma for example... This disease is commonly associated with the sudden onset of upper abdominal pain that is usually severe enough to warrant the patient seeking urgent medical attention. Overall, $10-25 \%$ of AP episodes are classified as severe. This leads to an associated mortality rate of $7-30 \%$ that has not changed in recent years. Treatment is conservative and generally performed by experienced teams often in ICUs. Although most cases of acute pancreatitis are uncomplicated and resolve spontaneously, the presence of complications has a significant prognostic importance. Necrosis, hemorrhage, and infection convey up to $25 \%, 50 \%$, and $80 \%$ mortality, respectively. Other complications such as pseudocyst formation, pseudo-aneurysm formation, or venous thrombosis, increase morbidity and mortality to a lesser degree. The presence of pancreatic infection must be avoided.

\title{
How to reference
}

In order to correctly reference this scholarly work, feel free to copy and paste the following:

Dirk Uhlmann (2012). Microcirculatory Disturbances in the Pathogenesis of Acute Pancreatitis, Acute Pancreatitis, Prof. Luis Rodrigo (Ed.), ISBN: 978-953-307-984-4, InTech, Available from:

$\mathrm{http}: / / \mathrm{www}$.intechopen.com/books/acute-pancreatitis/microcirculatory-disturbances-in-the-pathogenesis-ofacute-pancreatitis

\section{INTECH}

open science | open minds

\section{InTech Europe}

University Campus STeP Ri

Slavka Krautzeka 83/A

51000 Rijeka, Croatia

Phone: +385 (51) 770447

Fax: +385 (51) 686166

www.intechopen.com

\section{InTech China}

Unit 405, Office Block, Hotel Equatorial Shanghai

No.65, Yan An Road (West), Shanghai, 200040, China

中国上海市延安西路65号上海国际贵都大饭店办公楼 405 单元

Phone: +86-21-62489820

Fax: $+86-21-62489821$ 
(C) 2012 The Author(s). Licensee IntechOpen. This is an open access article distributed under the terms of the Creative Commons Attribution 3.0 License, which permits unrestricted use, distribution, and reproduction in any medium, provided the original work is properly cited. 